\title{
Characterization of Stress Corrosion Cracks in Ni-Based Weld Alloys 52, 52M and 152 Grown in High-Temperature Water
}

\author{
Yi Xie ${ }^{\mathrm{a}}$, Yaqiao $\mathrm{Wu}^{\mathrm{b}, \mathrm{c}}$, Jatuporn Burns ${ }^{\mathrm{b}, \mathrm{c}}$, Jinsuo Zhang ${ }^{\mathrm{a} *}$
}

\begin{abstract}
Ni-based weld alloys 52, 52M and 152 are extensively used in repair and mitigation of primary water stress corrosion cracking (SCC) in nuclear power plants. In the present study, a series of microstructure and microchemistry at the SCC tips of these alloys were examined with scanning electron microscopy (SEM), electron backscatter diffraction (EBSD), transmission electron microscopy (TEM), energy-dispersive X-ray spectroscopy (EDS), scanning transmission electron microscopy (STEM) and energy filtered transmission electron microscopy (EFTEM). The specimens have similar chemical compositions and testing conditions. Intergranular (IG) and transgranular (TG) SCC was observed in all of them. The cracks were filled with nickel-oxides and partial precipitations of chrome carbides $(\mathrm{CrCs})$, niobium carbides $(\mathrm{NbCs})$, titanium nitrides (TiNs) and silicon carbides ( $\mathrm{SiCs})$, while iron $(\mathrm{Fe})$ was largely dissolved into the solution. However, the crack densities, lengths and distributions were different for all three specimens.
\end{abstract}

\footnotetext{
${ }^{a}$ Nuclear Engineering Program, The Ohio State University, Columbus, OH 43210

${ }^{\mathrm{b}}$ Department of Materials Science and Engineering, Boise State University, Boise, ID 83725

${ }^{c}$ Center for Advanced Energy Studies, 995 University Blvd, Idaho Falls, ID 83401

* Corresponding author. Email: zhang.3558@ osu.edu; Phone: (614) 292-5405; Fax: (614) 292-

3163; Postal address: 201W 19th Ave, E428, Columbus, OH, 43210.
} 


\section{KEY WORDS}

Stress corrosion cracking; Scanning electron microscopy; Transmission electron microscopy; Nickel alloy 52/52M/152; Weld; Light water reactor

\section{INTRODUCTION}

Stress corrosion cracking (SCC) is a critical concern in high temperature water environments which are commonly found in light water reactors (LWRs) and other steam-based powergenerating systems. Understanding mechanisms of the degradation that precedes crack initiation is therefore of fundamental and practical interest. In LWRs, Ni-based weld alloys are significant structural materials, widely used in joining alloy components, e.g. the weldments of steam generators with stainless steel piping [1]. For such applications, they are expected to provide levels of high-temperature strength and corrosion resistance [2] and to reduce differences in thermal expansion coefficients between dissimilar based metals [3].

The development of new engineering alloys with improved strength and corrosion resistance is vital to energy production from LWRs. The Ni-based alloy 600 and its weld metals 82 and 182 (about 15 at.\% Cr content) have been used in LWRs since the 1960s because of good corrosion resistance in corrosive environments [4]. Unfortunately, they soon turned out to be susceptible to SCC in LWRs [5]. This has led to the replacement of more SCC resistant alloys with 30 at.\% $\mathrm{Cr}$ content, that is nickel alloy 690 and its weld metals 52, 52M and 152. Extra Cr enhances corrosion resistance in chemical solutions and high-temperature gasses, and the advanced alloys have been found to be highly resistant to IGSCC, IG attack and surface corrosion under simulated LWR primary water conditions [6] [7] [8] [9] [10]. However, the weldments continue to be a primary location of SCC because of the rapid cooling of molten metal from high 
temperatures, which leads to segregation, ductility dip cracking (DDC) and non-uniform thermal stresses (i.e. residual tensile stresses) [11]. Therefore, SCC of Ni-based weld alloys 52, 52M and 152 is still one of the key concerns of materials degradation in LWRs.

SCC of Ni-based alloys in the applications of LWRs has been extensively studied. Generally, it is concluded that Ni-based alloys with a number of carbides on grain boundaries (GBs) maybe more resistant to SCC [12] [13] [14] [15] [16] than the alloys with few carbides. Thermal treatments, that produce $\mathrm{CrCs}$ at the GBs, could improve SCC resistance of Ni-based alloys in the high purity water [17]. The studies of characteristics of defects (e.g. microstructural features, defect distributions, defect characteristics and weld residual strains) in the dilution zone of weld alloys 52, 52M and 152 show that both of TiNs and Cr-rich $\mathrm{M}_{23} \mathrm{C}_{6}$ exist on the GBs; while crack propagated along the precipitations of TiNs it stopped at $\mathrm{M}_{23} \mathrm{C}_{6}$ [18]. The precipitations behavior of TiNs/ TiCs and CrCs of weld alloy 52 and 52M were also found in the matrix [19]. In addition, more $\mathrm{Nb}$ and $\mathrm{Mo}$ contents in alloy 52M compared with 52 identified more precipitations of $\mathrm{NbCs}$, and $(\mathrm{Nb}, \mathrm{Ti}) \mathrm{Cs}$, which were found to raise the yield and tensile strengths. Last but not least, the additions of $\mathrm{Nb}$ and $\mathrm{Ti}$ to alloy 52 were found to improve the DDC susceptibility due to the precipitations of $\mathrm{NbC} / \mathrm{NbN}$, and TiC/TiN [20]. DDC typically manifests itself as IG cracks of one grain and will further propagate SCC [21] [22] [23] [24] [25]. Accordingly, the existence of carbides and nitrides of different elements especially $\mathrm{Cr}, \mathrm{Ti}$ and $\mathrm{Nb}$ are of high interest as they probably improve or depress the SCC resistance.

Considerable methods have been conducted on studying SCC. In order to fundamentally understand SCC behaviors in primary water environments, experiments on failure analysis were conducted by SCC propagation methods (e.g. [26] [27]) and microscopic morphology examinations (e.g. [18] [28] [29] [30]). Theories have been developed to describe SCC 
propagations [5] [31] [32]. The dominant mechanisms have been fundamentally concluded in various materials and environments, but further key issues need to be addressed. Microstructure and microchemistry observations of cracks are therefore vital to elucidate which specific processes influence the propagation. The purpose of the present study was to better understand the mechanisms of SCC of alloys 52/52M/152 in simulated primary water environments.

The study focused on analyzing the microstructure and microchemistry at the SCC tips. The microstructure features and SCC characteristics and distributions were examined by SEM and EBSD. Selected higher resolutions of crack microstructure and microchemistry were examined by TEM, EDS, STEM and EFTEM.

\section{EXPERIMENTAL}

\subsection{Specimens}

Three standard $1.27 \mathrm{~cm}$ (0.5 inch) thick compact tension (CT) specimens (Figure 1), containing weld alloy 52 (CT032), weld alloy 52M (CT042) and weld alloy 152 (CT052) ${ }^{\mathrm{a}}$, were provided by the research group of Doc. Bruemmer's in Pacific Northwest National Laboratory (PNNL), Richland, WA. Table 1 shows the nominal chemical compositions of the alloys. During the welding process, care was taken to set the geometric crack plane of each specimen parallel to the long axis of GBs as was perceived to be the most susceptible crack path. The specimens were polished to a high luster $(1 \mu \mathrm{m})$ using colloidal silica as the final polishing agent.

a The following paper uses "alloy 52", "alloy 52M", and "alloy 152" to represent the specimens. 


\subsection{Test procedure}

SCC tests were conducted on the PNNL SCC test system. For more detailed information about the system refer to the report [33]. Each specimen was independently tested and the crack growth mechanism was similar. They were first fatigue pre-cracked in the air and followed by further SCC extension using cyclic loading (and constant $\mathrm{K}$ loading in some test phases) in the simulated LWR primary water environment. The environment was high temperature deionizing water with 0.2 wt.\% boric acid, 0.0002 wt.\% lithium hydroxide and $11-29 \mathrm{~cm}^{3} / \mathrm{kg}$ hydrogen from 350 to $360{ }^{\circ} \mathrm{C}^{\mathrm{a}}$. The specimens were stressed by a tensile machine (capable of $22 \mathrm{kN}$ maximum load) with cyclic (0.001 to $5 \mathrm{~Hz}$ loading frequency) and constant $\mathrm{K}$ loading. The crack extension was in situ monitored by direct current potential drop (DCPD) approach with length resolution at $1 \mu \mathrm{m}$. Total test time for each specimen was around 5,000 hours. A summary of test conditions and corrected data for each phase of each specimen is shown in Tables 2- 4 [34].

\subsection{Characterization}

The microstructure and microchemistry characterization was analyzed at the Microscopy and Characterization Suite, Center for Advanced Energy Studies, Idaho Falls, ID.

After SCC tests, each specimen was sealed and mounted for crack-tip characterization by filling it with epoxy resin. After the resin, each specimen was abrasively cut with diamond type cutting wheels with the preservation of axe orientation. Coarse grit silicon carbides abrasives, fine diamond polishing papers and colloidal silica were used to grind and polish the surface to a high luster. The specimen surface images and crack images of high resolution were captured by the

\footnotetext{
${ }^{\text {a }}$ Crack growth at $50{ }^{\circ} \mathrm{C}$ was performed on alloy 52 to promote IG cracking (more details are displayed on Table 2).
} 
FEI Quanta 3D FEG FIB. Crystallographic orientations were detected by the EBSD microstructural-crystallographic technique.

Analysis of localized degradation phenomena required the preparation of site-specific specimens; therefore the TEM lamellas were made by FIB at the crack tips for the further nano- and microscale analysis by the FEI Tecnai $G^{2}$ F30 STEM. They were extracted using the standard FIB liftout method and populated onto a Si micro-post array. The top $20 \mu \mathrm{m}$ of several Si micro-posts were detached from the array and affixed to the apex of the commercial five-prong TEM half grids. Ion millings were later continued to develop thin areas suitable for TEM analysis, with final millings performed at reduced energy and beam incidence $(2 \mathrm{keV}, \pm 4$ degree $)$ to minimize the superficial ion-beam damage. Repeated cycles of ion millings and examinations were used to progressively thin the cracks for better examinations. Four $10 \mu \mathrm{m} \times 10 \mu \mathrm{m} \times 50 \mathrm{~nm}$ TEM lamellas were separately made from weld alloy 52 (two), weld alloy 52M (one) and weld alloy 152 (one).

The FEI Tecnai $\mathrm{G}^{2}$ F30 STEM was operated to take nano- and microscopic images both at TEM and STEM modes. The EDS and EFTEM analytical techniques were taken for elemental analyses. FEI TIA (ESVison) software was applied to analyze EDS data. EFTEM technique, which is accurate to determine the formation of precipitations, was used to aid the elemental analyses and to improve the accuracy of mapping where more than one element was involved. 


\section{RESULTS AND DISCUSSION}

\subsection{Surface magnification}

Figure 2a is the SEM image displaying the whole crack of alloy 52. Secondary micro-cracks normal to the main crack have been observed. The main crack is filled by a number of round or irregular particles and discontinuous holes (Figure 2b) and fibrous conglomerations in micron size (Figure 2c). Alloy 52M and alloy 152 have similar morphology.

\subsection{Grain and grain boundary}

The characteristics of GB at the crack tip were examined by EBSD. The approach can examine the crystallographic orientation by focusing an electron beam on a point and record the backscatter diffraction pattern, and therefore identify the grain structure.

Figure 3 is the EBSD map of the whole crack of alloy 52M. The grain shape is highly varied. Red, green and blue respectively represents the crystal orientation of 001, 101 and 111 zone axis that is normal to the specimen surface (shown in the inset legend). Mis-orientation angle accompanied by an axis of rotation was used to describe GBs. Low angle was set as the misorientation angle between grains was less than 15-degree.

The main crack of alloy $52 \mathrm{M}$ propagated through a large grain as well as some extremely small grains (Figure 3). The TG crack is straight throughout the grain and encounters a GB at the end of the main crack. Figure 3 shows very large elongated grains with apparently low susceptibility to IG cracking. Considering the steep angle of GBs to the geometric crack plane, it may be the reason that the main crack did not favorably grow along the GBs. 
The local recrystallization may play a role in the cracking process. The typical large elongated grains can be seen with a collection of very fine grains along certain GBs in the middle of Figure 3. Previous literature did not show the recrystallization of alloy $52 \mathrm{M}$, but this study shows the existence. Most of the fine grains that are associated with the TG cracks are perceived to be local recrystallization of a large grain during the extension. The other possibility of the fine grains is because the grains are normal to the observed surface that only the transverse sections of grains were observed. Compared with the second reason, local recrystallization is a greater possibility as that the color gradient below and above the main crack indicates significant plastic deformations that might cause local recrystallization. In addition, the grains would be arranged in the same direction during the welding process, accordingly weakening the second reason.

Figure 4 is the EBSD map of the whole crack of alloy 52. The grains are in 500-1000 $\mu \mathrm{m}$ of sizes and varied of shapes and orientations. The geometric crack path is aligned with the boundaries of the elongated grains. The TG pre-crack ended at the high angle GB and branched into IG and TG cracks with irregularly extended secondary cracks on the [111]-orientated large grain (Figure $4 \mathrm{~b}$ ). The branched cracks finally converged into one main crack which propagated along the high angle GB up to $1 \mathrm{~mm}$ length. The color gradient below and above the crack indicates significant plastic deformation. At the end of tests, the cracking turned off the high angle GB and branched into three micro-cracks (Figure 4c). Two micro-cracks developed into the [111]- orientated grain, and another one kept propagating in the GB. This specimen has preference for IG cracking, probably caused by the good alignment of GBs and the geometric crack path.

Figure 5 is the EBSD map of the whole crack of alloy 152 . The grains are highly elongated of 1$2 \mathrm{~mm}$ long and 250-500 $\mu \mathrm{m}$ wide. The pre-crack ended at the high angle GB. Generally, it 
should have propagated along the GB, however, it turned off the pre-cracking direction and propagated into the elongated grain. What can be unambiguously determined from the figure is that this specimen is TG SCC susceptible, having no tendency for the degree of IG engagement to improve.

\subsection{Crack tip cross section}

At the crack tip, IG SCC occurred in alloy 52 and TG SCC occurred in all the specimens. The lamellas were tilted in TEM to apply two-beam condition to image defects and characteristics of the crack tips cross sections and were observed under TEM bright-field mode. Figure 6 shows the dislocations (crystallographic defects) formed around the crack tips. Alloy 52 has lower dislocation densities than alloys 52M and 152. The voids or pores of oxides (based on the EDS analysis) along the crack indicate the oxidation occurred after the formation of crack.

The chemical compositions of the bulk materials (far from crack areas) were detected by EDS quantitative analysis (Table 5). Due to the nature that the light elements absorb much more Xrays than the heavier elements, the quantitative EDS analysis results of the content of light elements, in particular $\mathrm{C}$ and $\mathrm{N}$, are not as accurate as that of heavier elements. EFTEM technique, is more sensitive on light elements than the EDS, which will be discussed in section 3.4 to reveal the existence of carbides and nitrides.

\subsection{Crack microchemistry}

Figure 7 (a) and (b) show STEM Z-contrast image of the TG crack in alloy 52 and corresponding EDS line scan results from the matrix to crack center along a red line, respectively. The concentration profiles in Figure 7 (b) are normalized as $\mathrm{Ni}+\mathrm{Cr}+\mathrm{Fe}+\mathrm{O}=100$ at. $\%$. The total 
count from X-ray signals received by the EDS detector is decreasing from the bulk material to the outer oxide layer, probably due to the diffusion of bulk material, forming the oxides and dissolving into water. However, the counts from the EDS result depends on specimen thickness and element number at the location where energy beam hits, so the lowered counts may be caused by the thinner precipitations inside the crack as well as a lighter element than others in the alloys (e.g. O will absorb more X-rays than others, contributing to decreased X-ray signals).

O content is gradually elevated from the bulk material to the outer oxide layer due to oxidation. $\mathrm{Fe}$ and $\mathrm{Fe}-\mathrm{O}$ were rarely detected as they have dissolved into water. The inner oxide layer is compact and mainly composed of $\mathrm{Cr}-\mathrm{O}$. The outer oxide layer is loose and has a colummner morphology, mainly composed of Ni-O. The concentration of $\mathrm{Cr}$ in the inner oxide layer slightly increases as other elements were outward diffused. In the outer oxide layer (see the red line at the distance $400 \mathrm{~nm}$ ), Cr content is extremely low because the diffusion coefficient of $\mathrm{Cr}$ is extremely small. Most $\mathrm{Cr}$ was kept in the inner oxide layer and did not move outward to form oxides. Conversely, the diffusion coefficient of $\mathrm{Ni}$ through the inner layer is large enough to make Ni diffuse outward and react with water to form oxides by oxidation or re-deposition. Therefore, Ni content sharply increases at the interface of inner oxide layer and outer oxide layer.

Figure 8 gives alloy 52 TG crack EFTEM elemental mappings of $\mathrm{Cr}, \mathrm{C}, \mathrm{Ti}, \mathrm{N}, \mathrm{Nb}, \mathrm{O}$ and zeroloss (ZL) image at the same area. $\mathrm{Cr}$ concentration in the outer oxide layer is much lower than that in the inner oxide layer, coinciding with the Cr content result in Figure 7 (b). The mappings of $\mathrm{Cr}$ and $\mathrm{O}$ certify the distribution of $\mathrm{Cr}-\mathrm{O}$ as discussed. TiNs, $\mathrm{NbCs}$ and SiCs probably exist at the crack according to the contrast of mappings. The alloy 52 IG crack also has the precipitations of TiNs and SiCs as shown in Figure 9. 
Figure 10 (a) and (b) show the STEM Z-contrast image of a crack in the alloy 52M and corresponding EDS line scan results from the matrix to crack center along a red line, respectively. Cr content was largely reduced from $\sim 44.8 \%$ to $\sim 2.8 \%$ because of its low diffusion coefficient. While at the interface between the inner oxide layer and the outer oxide layer, $\mathrm{Cr}$ content rises from $\sim 43.0 \%$ (at distance $100 \mathrm{~nm}$ ) to $\sim 53.5 \%$ (at distance $130 \mathrm{~nm}$ ) and then drops (at distance $150 \mathrm{~nm}$, the red vertical line). Figure 7 also displays this phenomenon as between the distance $345 \mathrm{~nm}$ and $388 \mathrm{~nm} \mathrm{Cr}$ content rises from $~ 33.2 \%$ to $~ 39.4 \%$ and then drops. Ni content is low at the interface. Like alloy 52, the outer oxide particles are mainly composed of Ni-O and slight of Fe.

Figure 11 is alloy 52M TG crack EFTEM elemental mappings of $\mathrm{Cr}, \mathrm{C}, \mathrm{Ti}, \mathrm{N}, \mathrm{Nb}$ and zero-loss (ZL) image. The $\mathrm{Cr}$ mapping proves the extremely low concentration of $\mathrm{Cr}$ in outer oxide particles (see the $\mathrm{Cr}$ concentration of Figure 10). Similar to alloy 52, it displays few precipitations of $\mathrm{CrCs}$ at the interface of oxide layers. However, it has high density of precipitations of TiNs, $\mathrm{NbCs}$ and $\mathrm{SiCs}$.

Figure 12 (a) and (b) show the STEM Z-contrast image of a crack in the alloy 152 and corresponding EDS line scan results from the matrix to crack center along a red line, respectively. The $\mathrm{Ni}$ and $\mathrm{O}$ contents indicate the penetrative $\mathrm{TG}$ attack is filled with porous, fine-grained Ni-oxide. At the interface between two oxide particles (at distance $70 \mathrm{~nm}$, see the red vertical line), Fe content has slight increment which indicates Fe oxide was deposited. The nanocrystalline oxide area and the oxide particles (like other specimens) both have extremely low $\mathrm{Cr}$ content, indicating no Cr oxide. 
Figure 13 is the alloy 152 TG crack EFTEM elemental mappings of $\mathrm{Cr}, \mathrm{Fe}, \mathrm{Ti}, \mathrm{C}, \mathrm{Nb}$ and $\mathrm{N}$. Different from the other specimens, these oxides are Fe enriched. Plenty of $\mathrm{CrCs}$, NbCs and TiNs are precipitated. The discontinuous nature of the $\mathrm{Cr}-\mathrm{C}$ phase indicates $\mathrm{Cr}$ is enriched along only portions of the crack. Carbides are semi-continuous and decorate nearly the entire crack cross section. However, alloy 52 TG crack does not reveal any precipitations of CrCs (Figure 8).

In summary, precipitations of carbides and nitrides have been observed in all three specimens, their densities being different. Alloy 152 has many precipitations of carbides in the crack area, in opposite to the other two specimens. This might be caused by the insufficient time to reach equilibrium with the bulk during annealing. NbCs and TiNs have the same morphology and should take the similar function as CrCs. Carbides and nitrides can lock the grain and reduce the separation of grains, being vital for corrosion protection, while making the surrounding matrix corrosion susceptible. When the $\mathrm{Cr}$ is depleted by precipitation such as $\mathrm{CrCs}$ as shown in Figure 13, the corrosion resistance is reduced, which leads to $\mathrm{Ni}$ oxide particle formation at the crack area [35].

Precipitations of carbides and nitrides can modify the GB morphology, increasing the GB tortuosity accordingly. Straight GBs cause strain concentrated at the triple points, having lower resistance to GB sliding than the ones of tortuous GBs. Alloys with precipitations of carbides and nitrides are more SCC resistant than the ones without.

IG and TG cracks have been observed in alloy 52 (Figure 4), while only TG cracks have been observed in the other two specimens (Figure $3 \& 5$ ). The crack path would depend on the ending of pre-crack and grain orientations relative to the stress direction. The air pre-crack ended at the triple point of grains, assisting the crack propagation along the boundary; GBs aligned with the 
target crack growth direction caused by the stress, reduced the sliding resistance to SCC as well as the tendency to go off the boundary. Both conditions resulted in the IG cracking of alloy 52. However, it is extremely difficult to draw conclusions on such weld metals, as more welds and cracks would have to be studied in detail to see if there are preferred crack paths and the weak or strong locations.

Although TEM can successfully determine the composition and crystallography associated with oxidation in the specimens, it is important to note that the projection technique, that integrates information through the thickness of the TEM lamella $(<70 \mathrm{~nm})$, can result in uncertainty about the three-dimensional nature of those observations. Furthermore, it is very difficult to detect small changes in composition that would be expected with solid-state oxygen diffusion ahead of the fully formed oxides.

\section{CONCLUSIONS}

The study examined the microstructure and microchemistry of stress corrosion cracks in weld alloys 52, 52M and 152 grown in simulated PWR environment. Based on the study, the following conclusions may be drawn:

1) The crack densities, lengths and distributions in all three specimens are different. Alloy 52 is both IG and TG SCC susceptible while alloy 52M and 152 are TG SCC susceptible based on the present study. For alloy 52, the cracking process of IG and TG crack strongly dependent on the ending of pre-crack and grain size and grain orientation relative to the stress direction. GBs aligned with the target crack growth direction (Figure 4) reduce the tendency for cracks to go off the boundary. Small grains (e.g. alloy 52M the area of small grains, see Figure 3) increase the interaction frequency. 
2) Microchemistry analyses of all three specimens show that oxygen penetrated alloys and filled cracks with Ni-rich oxide particles. Fe largely dissolved into water during cracking.

3) Apparent difference of trace elements ( $\mathrm{Ti}, \mathrm{Nb}, \mathrm{C}$ and $\mathrm{N}$ ) at crack tips of all three specimens has not been observed. TiNs, NbCs and SiCs have been commonly observed at the interfaces between cracks and inner oxide layers, their sizes being between 100-200 nm (extremely small).

4) The precipitations of $\mathrm{CrCs}$ are not obvious except for the alloy 152. Precipitations of $\mathrm{NbCs}$ and $\mathrm{SiCs}$ might be prior to $\mathrm{CrCs}$ for alloy 52 and alloy $52 \mathrm{M}$.

5) The fabrication variables (e.g. forming process and annealing conditions) which control the carbides morphology are not considered in this study. It is difficult to discover the regular pattern to different fabrication variables. Every weld is unique and a large number of welds would have to be investigated to draw definitive conclusions.

Future research is needed to better understand the formation of weld cracks in the weld nickel alloys and their potential effects on subsequent PWR component reliability in service. Further characterization of these welds are planned to improve the understanding of the root cause of cracking. The intent will be to evaluate the influence of weld cracks and any associated microvariations on SCC initiation and propagation.

\section{ACKNOWLEDGMENTS}

This research has been performed using funding received from U.S Nuclear Regulatory Commission (Grant No. NRC-HQ-11-G-38-0036) and DOE-ATR Program. The specimens are supplied by the research group of Doc. Bruemmer's, in Pacific Northwest National Laboratory 
(PNNL), Richland, WA. Special thanks to the technique assistance from the Center for Advanced Energy Studies (CAES), Idaho Falls, ID.

\section{REFERENCES}

[1] J. W. Kim, K. Lee, J. S. Kim and T. S. Byun, "Local mechanical properties of Alloy 82/182 dissimilar weld joint between SA508 Gr.1a and F316 SS at RT and $320{ }^{\circ} \mathrm{C}, " J$. Nucl. Mater., vol. 384, no. 3, pp. 212-221, 2009.

[2] J. N. Dupont, "Welding of Nickel-Based Alloys for Energy Applications," Weld. J., vol. 93, pp. 31s-45s, 2014.

[3] M. Sireesha, S. K. Albert, V. Shankar and S. Sundaresan, "A comparative evaluation of welding consumables for dissimilar welds between 316LN austenitic stainless steel and Alloy 800," J. Nucl. Mater., vol. 279, no. 1, pp. 65-76, 2000.

[4] J. Gorman, S. Hunt and P. Riccardella, "PWR reactor vessel alloy 600 issues," in Companion guide to the ASME boiler \& pressure vessel code, Amer Society of Mechanical, 2001, pp. 66-84.

[5] Materials Reliability Program (MRP), "Resistance to Primary Water Stress Corrosion Cracking of Alloys 690, 52, and 152 in Pressurized Water Reactors (MRP-111)," EPRI, Palo Alto, CA, 2004.

[6] R. A. Page, "Stress Corrosion Cracking of Alloys 600 and 690 and Nos. 82 and 182 Weld Metals in High Temperature Water," Corrosion, vol. 39, no. 10, pp. 409-421, 1983.

[7] R. A. Page and A. McMinn, "EPRI NP-5882M Project 1566-1," EPRI, 1988.

[8] H. C. Burghard and A. J. Bursle, "SWRI Project 02-5839-001," SWRI, 1978.

[9] G.-P. Yu and H.-C. Yao, "he Relation Between the Resistance of IGA and IGSCC and the Chromium Depletion of Alloy 690," Corrosion, vol. 46, no. 5, pp. 391-402, 1990.

[10] D. Choi and G. S. Was, "Pit growth in alloy 600/690 steam generator tubes in simulated concentrated environments," Corrosion, vol. 46, no. 2, pp. 100-111, 1990. 
[11] J. R. Crum and R. C. Scarberry, "Corrosion testing of Inconel alloy 690 for PWR steam generators," J. Mater. Energy Syst., vol. 4, no. 3, pp. 125-130, 1982.

[12] "Stress Corrosion Cracking In Light Water Reactors: Good Practices and Lessons Learned," International Atomic Energy Agency, VIENNA, 2011.

[13] J. L. Hertzberg and G. S. Was, "Isolation of Carbon and Grain Boundary Carbide Effects on the Creep and Intergranular Stress Corrosion Cracking Behavior of Ni-16Cr-9Fe-xC Alloys in 360 degC Primary Water," Metall. Mater. Trans.A, vol. 29A, pp. 1035-1046, 1998.

[14] M. Sennour, P. Laghoutaris, C. Guerre and R. Molins, "Advanced TEM characterization of stress corrosion cracking of Alloy 600 in pressurized water reactor primary water environment," J. Nucl. Mater., vol. 393, p. 254, 2009.

[15] J. P. Foster, W. H. Bamford and R. S. Pathania, "Initial Results of Alloy 600 Crack Growth Rate Testing in a PWR Environment," in 7th Inter. Symp. On Environmental Degradation of Materials in Nuclear Power Systems- Water Reactors: NACE International, Houston, TX, 1995.

[16] T. Yamada, T. Terachi and K. Arioka, in Corrosion, Houston, TX, 2008.

[17] H. Coriou, J. Blanchet, L. Grall, C. Mahhiew, C. Otter and G. Turfer, "Historical review of the principal research concerning the phenomenon of cracking of nickel-base austenitic alloys," in Stress Corrosion Cracking and Hydrogen Embrittlement of Iron-Base Alloys, National Association of Corrosion Engineers, 1977, pp. 1149-1160.

[18] S. M. Bruemmer, M. B. Toloczko, M. J. Olszta, R. Seffens and P. Efsing, "Characterization of defects in alloy 152, 52, and 52M welds," [Online]. Available: http://pbadupws.nrc.gov/docs/ML0924/ML092460211.pdf. [Accessed 10 Dec 2014].

[19] S.-L. Jeng and Y.-H. Chang, "MicrostructureandflowbehaviorofNi-Cr-Fewelds with $\mathrm{Nb}$ and Mo additions," Mater. Sci. Eng. A, vol. 560, pp. 343-350, 2013.

[20] A. J. Ramirez, J. W. Sowards and J. C. Lippold, "Improving the ductility-dip cracking resistance of Ni-base alloys," J. Mater. Process. Technol., vol. 179, no. 1, pp. 212-218, 2006.

[21] A. J. Ramirez and J. C. Lippold, "High temperature behavior of Ni-base weld metal: Part I. Ductility and microstructural characterization," Mater. Sci. Eng. A, vol. 380, no. 1, pp. 259-271, 2004. 
[22] A. J. Ramirez and J. C. Lippold, "High temperature behavior of Ni-base weld metal: Part II-Insight into the mechanism for ductility dip cracking," Mater. Sci. Eng. A, vol. 380, no. 1, pp. 245-258, 2004.

[23] M. G. Collins, A. J. Ramirez and J. C. Lippold, "An investigation of ductility-dip cracking in Ni-base filler metals-Part 2," Weld. J., vol. 82, no. 12, pp. 348s-354s, 2003.

[24] M. G. Collins, A. J. Ramirez and J. C. Lippold, "An investigation of ductility-dip cracking in Ni-base filler metals-Part 3," Weld. J., vol. 83, no. 2, pp. 39s-49s, 2004.

[25] G. A. Young, T. E. Capobrianco, M. A. Penik, B. W. Morris and J. J. McGee, "The Mechanism of Ductility Dip Cracking in Nickel-Chromium Alloys," Weld. J., vol. 87, pp. 31-43, 2008.

[26] M. B. Toloczko, M. J. Olszta, N. J. Overman and S. M. Bruemmer, "Observations and implications of intergranular stress corrosion crack growth of alloy 152 weld metals in simulated PWR primary water," [Online]. Available:

http://pbadupws.nrc.gov/docs/ML1322/ML13220A049.pdf. [Accessed 10 Dec 2014].

[27] P. Andresen, M. Morra and A. Ahluwalia, "SCC of alloy 52\& 152 weld metals in PWR primary water," in NRC-EPRI Meeting, 2011.

[28] W. Wu and C. H. Tsai, "Hot Cracking Susceptibility of Fillers 52 and 82 in Alloy 690 Welding," Metall. Mater.transactions A, vol. 30A, pp. 417-426, 1999.

[29] S. M. Bruemmer, M. J. Olszta, M. B. Toloczko and L. E. Thomas, "Linking Grain Boundary Microstructure to Stress Corrosion Cracking of Cold-Rolled Alloy 690 in Pressurized Water Reactor Primary Water," Corrosion, vol. 69, no. 10, pp. 953-963, 2013.

[30] M. Olszta, D. Schreiber, L. Thomas and S. Bruemmer, "High-Resolution Crack Imaging Reveals Degradation Processes in Nuclear Reactor Structural Materials," Advanced Materials \& Processes, vol. 170, no. 4, pp. 17-21, 2012.

[31] O. F. Aly and M. M. Neto, "Stress Corrosion Cracking," in Developments in Corrosion Protection, InTech, 2014, pp. 65-79.

[32] R. W. Staehle, "Serious Concerns and Actions for Mitigating Future Degradation in Modern Steam Generators," in The 5th CNS International Steam Generator Conference, Toronto, Ontario, CA, 2006.

[33] S. M. Bruemmer and M. B. Toloczko, "Pacific Northwest National Laboratory Investigation of Stress Corrosion Cracking in Nickel-Base Alloys (NUREG/CR-7103, 
Volume 1, PNNL-16613)," U.S. Nuclear Regulatory Commission, Washington, DC, 2011.

[34] S. M. Bruemmer, M. B. Toloczko and M. J. Olszta, "Pacific Northwest National Laboratory investigation of stress corrosion cracking in nickel-base alloys (NUREG/CR7103, Volume 2)," U.S. Nuclear Regulatory Commission, Washington, DC, 2012.

[35] S. S. Hwang, Y. S. Lim, S. W. Kim, D. J. Kim and H. P. Kim, "Role of grain boundary carbides in cracking behavior of Ni base alloys," Nucl. Eng. Technol., vol. 45, no. 1, pp. 73-80, 2013. 


\section{Table Captions}

Table 1 Nominal chemical composition of alloy 52, alloy 52M and alloy 152.

Table 2 Summary of test conditions of alloy 52 [34].

Table 3 Summary of test conditions of alloy 52M [34].

Table 4 Summary of test conditions of alloy 152 [34].

Table 5 Bulk compositions of the specimens detected by EDS.

\section{Figure Captions}

Figure 1 Diagram of the $1.27 \mathrm{~cm}(0.5 \mathrm{inch})$ thickness compact tension specimen (unit: $\mathrm{cm})$.

Figure 2 SEM of the whole crack of alloy 52 surface.

Figure 3 Alloy 52M SEM/EBSD micrographs of grains and crack.

Figure 4 Alloy 52 SEM/EBSD micrographs of grains and crack.

Figure 5 Alloy 152 SEM/EBSD micrographs of grains and crack.

Figure 6 TEM bright-field images (a) alloy 52 IG crack (b) alloy 52 TG crack (c) alloy 52M IG crack (d) alloy $152 \mathrm{TG}$ crack.

Figure 7 (a) STEM image of a crack in alloy 52 TG. EDS linescan was performed along the red line; and (b) corresponding EDS concentration profiles of $\mathrm{Ni}, \mathrm{Cr}, \mathrm{Fe}, \mathrm{O}$ measured from the linescan..

Figure 8 EFTEM zero-loss (ZL) image and elemental maps of alloy 52 TG crack. 
Figure 9 EFTEM zero-loss (ZL) image and elemental maps of alloy 52 IG crack.

Figure 10 (a) STEM image of a crack in alloy 52M IG. EDS linescan was performed along the red line; and (b) corresponding EDS concentration profiles of $\mathrm{Ni}, \mathrm{Cr}, \mathrm{Fe}, \mathrm{O}$ measured from the linescan.

Figure 11 EFTEM zero-loss (ZL) image and elemental maps of alloy 52M IG crack.

Figure 12 (a) STEM image of a crack in alloy 152 TG. EDS linescan was performed along the red line; and (b) corresponding EDS concentration profiles of $\mathrm{Ni}, \mathrm{Cr}, \mathrm{Fe}, \mathrm{O}$ measured from the linescan.

Figure 13 EFTEM zero-loss (ZL) image and elemental maps of alloy 152 TG crack.

Table 1

\begin{tabular}{|l|l|l|l|l|l|l|l|l|}
\hline \multicolumn{10}{|c|}{ Chemical compositions (at. \%) } \\
\hline $\mathrm{Ni}$ & $\mathrm{Cr}$ & $\mathrm{Fe}$ & $\mathrm{C}$ & $\mathrm{Mn}$ & $\mathrm{Si}$ & $\mathrm{Al}$ & $\mathrm{Ti}$ & $\mathrm{N}$ \\
\hline 59.10 & 29.10 & 10.00 & 0.02 & 0.25 & 0.13 & 0.71 & 0.52 & 0.01 \\
\hline \multicolumn{10}{|c|}{ (b) Alloy $52 \mathrm{M}$} \\
\hline $\mathrm{Ni}$ & $\mathrm{Cr}$ & $\mathrm{Fe}$ & $\mathrm{C}$ & $\mathrm{Mn}$ & $\mathrm{Si}$ & $\mathrm{Al}$ & $\mathrm{Ti}$ & $\mathrm{Nb}+\mathrm{Ta}$ \\
\hline 59.90 & 30.00 & 7.90 & 0.01 & 0.75 & 0.13 & 0.11 & 0.21 & 0.81 \\
\hline \multicolumn{8}{|c|}{ (c) Alloy 152} \\
\hline $\mathrm{Ni}$ & $\mathrm{Cr}$ & $\mathrm{Fe}$ & $\mathrm{C}$ & $\mathrm{Mn}$ & $\mathrm{Si}$ & $\mathrm{Nb}$ & $\mathrm{Al}$ & $\mathrm{Ti}$ \\
\hline 55.23 & 28.70 & 10.40 & 0.05 & 3.50 & 0.41 & 1.45 & 0.06 & 0.09 \\
\hline
\end{tabular}


Table 2

\begin{tabular}{|c|c|c|c|c|c|c|c|c|c|}
\hline $\begin{array}{l}\text { Test } \\
\text { phase }\end{array}$ & $\begin{array}{l}\text { Durati } \\
\text { on (h) }\end{array}$ & $\mathrm{R}$ & $\begin{array}{c}\text { Frequenc } \\
\mathrm{y}(\mathrm{Hz})\end{array}$ & $\begin{array}{l}\text { Hold } \\
\text { (h) }\end{array}$ & $\begin{array}{l}\text { Water chemistry } \\
\text { conditions }\end{array}$ & $\begin{array}{c}\text { Temperature } \\
\left({ }^{\circ} \mathrm{C}\right)\end{array}$ & $\begin{array}{c}\mathrm{Kmax} \\
(\mathrm{MPa} \sqrt{\mathrm{m}})\end{array}$ & $\begin{array}{l}\text { CGR } \\
(\mathrm{m} / \mathrm{s})\end{array}$ & $\begin{array}{c}\text { Crack } \\
\text { extension } \\
(\mathrm{m})\end{array}$ \\
\hline 1 & $\sim 2$ & 0.3 & 3 & 0 & air precrack & room temp. & 25 & $1.5 \mathrm{E}-07$ & $5.80 \mathrm{E}-04$ \\
\hline 2 & $\sim 2$ & 0.5 & 3 & 0 & air precrack & room temp. & 28 & $1.1 \mathrm{E}-07$ & $4.60 \mathrm{E}-04$ \\
\hline 3 & $\sim 2$ & 0.6 & 3 & 0 & air precrack & room temp. & 31 & $6.8 \mathrm{E}-08$ & $3.50 \mathrm{E}-04$ \\
\hline 4 & $\sim 3$ & 0.7 & 3 & 0 & air precrack & room temp. & 31 & $3.4 \mathrm{E}-08$ & $3.50 \mathrm{E}-04$ \\
\hline 5 & 18 & 0.5 & 0.1 & 0.0 & $29 \mathrm{cc} / \mathrm{kg} \mathrm{H} 2$ & 350 & 31 & $6.0 \mathrm{E}-09$ & $3.01 \mathrm{E}-04$ \\
\hline 6 & 106 & 0.5 & 0.01 & 0.0 & $29 \mathrm{cc} / \mathrm{kg} \mathrm{H} 2$ & 350 & 31 & 7.9E-10 & $3.03 \mathrm{E}-04$ \\
\hline 7 & 421 & 0.5 & 0.001 & 0.0 & $29 \mathrm{cc} / \mathrm{kg} \mathrm{H} 2$ & 350 & 32 & $1.0 \mathrm{E}-10$ & $1.60 \mathrm{E}-04$ \\
\hline 8 & 60 & --- & constK & --- & $29 \mathrm{cc} / \mathrm{kg} \mathrm{H} 2$ & 50 & 32 & $<1.0 \mathrm{E}-12$ & $0.00 \mathrm{E}+00$ \\
\hline 9 & 37 & 0.5 & 0.1 & 0.0 & $29 \mathrm{cc} / \mathrm{kg} \mathrm{H} 2$ & 50 & 32 & 2.3E-09 & $2.34 \mathrm{E}-04$ \\
\hline 10 & 200 & 0.5 & 0.01 & 0.0 & $29 \mathrm{cc} / \mathrm{kg} \mathrm{H} 2$ & 50 & 32 & $2.5 \mathrm{E}-10$ & $2.08 \mathrm{E}-04$ \\
\hline 11 & 425 & 0.5 & 0.01 & 0.0 & $29 \mathrm{cc} / \mathrm{kg} \mathrm{H} 2$ & 50 & 32 & 3.9E-10 & $5.22 \mathrm{E}-04$ \\
\hline 12 & 192 & 0.5 & 0.01 & 0.0 & $29 \mathrm{cc} / \mathrm{kg} \mathrm{H} 2$ & 50 & 33 & 4.4E-10 & $2.12 \mathrm{E}-04$ \\
\hline 13 & 504 & --- & constK & --- & $29 \mathrm{cc} / \mathrm{kg} \mathrm{H} 2$ & 350 & 11 & $\begin{array}{c}\text { decreasin } \\
\mathrm{g}\end{array}$ & $2.50 \mathrm{E}-05$ \\
\hline 14 & 186 & 0.78 & 0.001 & 2.5 & $29 \mathrm{cc} / \mathrm{kg} \mathrm{H} 2$ & 350 & 11 & $2.7 \mathrm{E}-12$ & $2.40 \mathrm{E}-05$ \\
\hline 15 & 497 & 0.78 & 0.001 & 2.5 & $29 \mathrm{cc} / \mathrm{kg} \mathrm{H} 2$ & 350 & $11->33$ & $1.2 \mathrm{E}-11$ & $5.90 \mathrm{E}-05$ \\
\hline 16 & 367 & --- & constK & --- & $29 \mathrm{cc} / \mathrm{kg} \mathrm{H} 2$ & 350 & 33 & $\sim 5 \mathrm{E}-13$ & $<1.00 \mathrm{E}-6$ \\
\hline 17 & 136 & 0.78 & 0.001 & 2.5 & $29 \mathrm{cc} / \mathrm{kg} \mathrm{H} 2$ & 350 & $33->38$ & $2.4 \mathrm{E}-11$ & $2.00 \mathrm{E}-06$ \\
\hline 18 & 458 & --- & constK & -- & $29 \mathrm{cc} / \mathrm{kg} \mathrm{H} 2$ & 350 & 38 & $\sim 5 \mathrm{E}-13$ & $<1.00 \mathrm{E}-6$ \\
\hline 19 & 216 & 0.7 & 0.001 & 2.5 & $29 \mathrm{cc} / \mathrm{kg} \mathrm{H} 2$ & 350 & $38->39$ & $1.1 \mathrm{E}-11$ & $9.00 \mathrm{E}-06$ \\
\hline 20 & 86 & 0.7 & 0.001 & 2.5 & $29 \mathrm{cc} / \mathrm{kg} \mathrm{H} 2$ & 350 & $39->44$ & $5.0 \mathrm{E}-11$ & $9.00 \mathrm{E}-06$ \\
\hline 21 & 564 & 0.7 & 0.001 & 2.5 & $29 \mathrm{cc} / \mathrm{kg} \mathrm{H} 2$ & 350 & 44 & $1.1 \mathrm{E}-11$ & $2.20 \mathrm{E}-05$ \\
\hline 22 & 1034 & --- & constK & --- & $29 \mathrm{cc} / \mathrm{kg} \mathrm{H} 2$ & 350 & 44 & $\sim 5 \mathrm{E}-13$ & $1.00 \mathrm{E}-06$ \\
\hline
\end{tabular}




\section{Table 3}

\begin{tabular}{|c|c|c|c|c|c|c|c|c|c|}
\hline $\begin{array}{c}\text { Test } \\
\text { phase }\end{array}$ & $\begin{array}{c}\text { Duratio } \\
\mathrm{n}(\mathrm{h})\end{array}$ & $\mathrm{R}$ & $\begin{array}{c}\text { Frequency } \\
(\mathrm{Hz})\end{array}$ & $\begin{array}{c}\text { Hold } \\
(\mathrm{h})\end{array}$ & $\begin{array}{c}\text { Water chemistry } \\
\text { conditions }\end{array}$ & $\begin{array}{c}\text { Temperature } \\
\left({ }^{\circ} \mathrm{C}\right)\end{array}$ & $\begin{array}{c}\mathrm{Kmax} \\
\left(\mathrm{MPa} \sqrt{\mathrm{m}}^{2}\right)\end{array}$ & CGR $(\mathrm{m} / \mathrm{s})$ & $\begin{array}{c}\text { Crack } \\
\text { extension (m) }\end{array}$ \\
\hline 1 & $\sim 3$ & 0.3 & 5 & 0 & air precrack & room temp. & 21 & 3.7E-08 & 4.00E-04 \\
\hline 2 & $\sim 2$ & 0.5 & 5 & 0 & air precrack & room temp. & 23 & 2.2E-08 & $3.50 \mathrm{E}-04$ \\
\hline 3 & $\sim 2$ & 0.6 & 5 & 0 & air precrack & room temp. & 25 & $1.3 \mathrm{E}-08$ & $3.50 \mathrm{E}-04$ \\
\hline 4 & $\sim 3$ & 0.7 & 5 & 0 & air precrack & room temp. & 25 & 7.8E-09 & 2.00E-04 \\
\hline 5 & 86 & 0.7 & 0.1 & 0 & $20 \mathrm{cc} / \mathrm{kg} \mathrm{H} 2$ & 350 & 30 & 4.7E-10 & $2.02 \mathrm{E}-04$ \\
\hline 6 & 159 & 0.7 & 0.01 & 0 & $20 \mathrm{cc} / \mathrm{kg} \mathrm{H} 2$ & 350 & 30 & $9.1 \mathrm{E}-11$ & 4.90E-05 \\
\hline 7 & 49 & 0.5 & 0.01 & 0 & $20 \mathrm{cc} / \mathrm{kg} \mathrm{H} 2$ & 350 & 30 & 4.7E-10 & $9.80 \mathrm{E}-05$ \\
\hline 8 & 261 & 0.5 & 0.001 & 0 & $20 \mathrm{cc} / \mathrm{kg} \mathrm{H} 2$ & 350 & 30 & $6.7 \mathrm{E}-11$ & $6.00 \mathrm{E}-05$ \\
\hline 9 & 338 & 0.5 & 0.001 & 2.5 & $20 \mathrm{cc} / \mathrm{kg} \mathrm{H} 2$ & 350 & 30 & $1.3 \mathrm{E}-11$ & $1.90 \mathrm{E}-05$ \\
\hline 10 & 241 & 0.5 & 0.001 & 0 & $20 \mathrm{cc} / \mathrm{kg} \mathrm{H} 2$ & 350 & 30 & $5.3 \mathrm{E}-11$ & $4.00 \mathrm{E}-05$ \\
\hline 11 & 156 & 0.5 & $480 / 20$ & 0 & $20 \mathrm{cc} / \mathrm{kg} \mathrm{H} 2$ & 350 & 30 & $1.0 \mathrm{E}-10$ & $5.70 \mathrm{E}-05$ \\
\hline 12 & 193 & 0.5 & $980 / 20$ & 0 & $20 \mathrm{cc} / \mathrm{kg} \mathrm{H} 2$ & 350 & 30 & $6.1 \mathrm{E}-11$ & $4.20 \mathrm{E}-05$ \\
\hline 13 & 280 & 0.5 & 0.001 & 2.5 & $20 \mathrm{cc} / \mathrm{kg} \mathrm{H} 2$ & 350 & 30 & $9.4 \mathrm{E}-12$ & $1.20 \mathrm{E}-05$ \\
\hline 14 & 420 & --- & constK & --- & $20 \mathrm{cc} / \mathrm{kg} \mathrm{H} 2$ & 350 & 30 & $1.2 \mathrm{E}-12$ & $4.00 \mathrm{E}-06$ \\
\hline 15 & 405 & 0.6 & 0.001 & 0 & $20 \mathrm{cc} / \mathrm{kg} \mathrm{H} 2$ & 350 & 30 & $3.4 \mathrm{E}-11$ & $4.00 \mathrm{E}-05$ \\
\hline 16 & 265 & 0.6 & 0.001 & 2.5 & $20 \mathrm{cc} / \mathrm{kg} \mathrm{H} 2$ & 350 & 30 & $6.3 \mathrm{E}-12$ & $1.00 \mathrm{E}-05$ \\
\hline 17 & 175 & 0.5 & 0.001 & 1 & $20 \mathrm{cc} / \mathrm{kg} \mathrm{H} 2$ & 350 & 30 & $1.6 \mathrm{E}-11$ & $9.00 \mathrm{E}-06$ \\
\hline 18 & 43 & 0.5 & 0.001 & 1 & $20 \mathrm{cc} / \mathrm{kg} \mathrm{H} 2$ & 350 & $30->35$ & $1.0 \mathrm{E}-10$ & $1.40 \mathrm{E}-05$ \\
\hline 19 & 413 & 0.5 & 0.001 & 1 & $20 \mathrm{cc} / \mathrm{kg} \mathrm{H} 2$ & 350 & 35 & $3.2 \mathrm{E}-11$ & $6.70 \mathrm{E}-05$ \\
\hline 20 & 190 & 0.5 & 0.001 & 2.5 & $20 \mathrm{cc} / \mathrm{kg} \mathrm{H} 2$ & 350 & 35 & $1.4 \mathrm{E}-11$ & $1.00 \mathrm{E}-05$ \\
\hline 21 & 355 & 0.5 & 0.001 & 2.5 & $25 \mathrm{cc} / \mathrm{kg} \mathrm{H} 2$ & 360 & 35 & $1.6 \mathrm{E}-11$ & $1.90 \mathrm{E}-05$ \\
\hline 22 & 1289 & --- & constK & --- & $25 \mathrm{cc} / \mathrm{kg} \mathrm{H} 2$ & 360 & 35 & $1.1 \mathrm{E}-12$ & $3.00 \mathrm{E}-06$ \\
\hline
\end{tabular}


Table 4

\begin{tabular}{|c|c|c|c|c|c|c|c|c|c|}
\hline Test phase & Duration (h) & $\mathrm{R}$ & Frequency $(\mathrm{Hz})$ & $\begin{array}{l}\text { Hold } \\
\text { (h) }\end{array}$ & $\begin{array}{c}\text { Water } \\
\text { chemistry } \\
\text { conditions }\end{array}$ & $\begin{array}{c}\text { Temperature } \\
\left({ }^{\circ} \mathrm{C}\right)\end{array}$ & $\underset{(\mathrm{MPa} \sqrt{ } \mathrm{m})}{\mathrm{Kmax}}$ & $\begin{array}{l}\text { CGR } \\
(\mathrm{m} / \mathrm{s})\end{array}$ & $\begin{array}{c}\text { Crack } \\
\text { extension } \\
(\mathrm{m})\end{array}$ \\
\hline 1 & $\sim 3$ & 0.3 & 5 & 0 & air precrack & room temp. & 21 & --- & $4.00 \mathrm{E}-04$ \\
\hline 2 & $\sim 2$ & 0.5 & 5 & 0 & air precrack & room temp. & 23 & --- & $3.50 \mathrm{E}-04$ \\
\hline 3 & $\sim 2$ & 0.6 & 5 & 0 & air precrack & room temp. & 25 & --- & $3.50 \mathrm{E}-04$ \\
\hline 4 & $\sim 3$ & 0.7 & 5 & 0 & air precrack & room temp. & 25 & --- & $2.00 \mathrm{E}-04$ \\
\hline 5 & 6 & 0.5 & 0.1 & 0 & $25 \mathrm{cc} / \mathrm{kg} \mathrm{H} 2$ & 360 & 29 & $6.8 \mathrm{E}-09$ & $1.21 \mathrm{E}-04$ \\
\hline 6 & 50 & 0.5 & 0.01 & 0 & $25 \mathrm{cc} / \mathrm{kg} \mathrm{H} 2$ & 360 & 29 & $1.3 \mathrm{E}-06$ & $2.14 \mathrm{E}-04$ \\
\hline 7 & 201 & 0.5 & 0.001 & 0 & $25 \mathrm{cc} / \mathrm{kg} \mathrm{H} 2$ & 360 & 29 & $1.8 \mathrm{E}-07$ & $1.17 \mathrm{E}-04$ \\
\hline 8 & 45 & 0.5 & 0.01 & 0 & $25 \mathrm{cc} / \mathrm{kg} \mathrm{H} 2$ & 360 & 28 & 4.1E-07 & $7.50 \mathrm{E}-05$ \\
\hline 9 & 3 & 0.5 & 0.1 & 0 & $25 \mathrm{cc} / \mathrm{kg} \mathrm{H} 2$ & 360 & 28 & $3.8 \mathrm{E}-09$ & $2.70 \mathrm{E}-05$ \\
\hline 10 & 12 & 0.5 & 0.01 & 0 & $25 \mathrm{cc} / \mathrm{kg} \mathrm{H} 2$ & 360 & 28 & $1.0 \mathrm{E}-09$ & $1.90 \mathrm{E}-05$ \\
\hline 11 & 113 & 0.5 & 0.001 & 0 & $25 \mathrm{cc} / \mathrm{kg} \mathrm{H} 2$ & 360 & 27 & $5.0 \mathrm{E}-11$ & $2.20 \mathrm{E}-05$ \\
\hline 12 & 160 & 0.5 & 0.001 & 2.5 & $25 \mathrm{cc} / \mathrm{kg} \mathrm{H} 2$ & 360 & 27 & $9.3 \mathrm{E}-12$ & $1.00 \mathrm{E}-05$ \\
\hline 13 & 153 & 0.5 & 0.001 & 1 & $25 \mathrm{cc} / \mathrm{kg} \mathrm{H} 2$ & 360 & 27 & $7.8 \mathrm{E}-12$ & $6.00 \mathrm{E}-06$ \\
\hline 14 & 158 & 0.78 & 0.001 & 2.5 & $25 \mathrm{cc} / \mathrm{kg} \mathrm{H} 2$ & 360 & 27 & $5.0 \mathrm{E}-12$ & $4.00 \mathrm{E}-06$ \\
\hline 15 & 362 & --- & const $\mathrm{K}$ & --- & $25 \mathrm{cc} / \mathrm{kg} \mathrm{H} 2$ & 360 & 27 & $2.9 \mathrm{E}-12$ & $4.00 \mathrm{E}-06$ \\
\hline 16 & 297 & 0.5 & 0.001 & 1 & $25 \mathrm{cc} / \mathrm{kg} \mathrm{H} 2$ & 360 & 27 & $6.0 \mathrm{E}-12$ & $3.00 \mathrm{E}-06$ \\
\hline 17 & 208 & 0.5 & 0.001 & 2.5 & $25 \mathrm{cc} / \mathrm{kg} \mathrm{H} 2$ & 360 & 27 & $3.6 \mathrm{E}-12$ & $2.00 \mathrm{E}-06$ \\
\hline 18 & 201 & --- & constK & --- & $25 \mathrm{cc} / \mathrm{kg} \mathrm{H} 2$ & 360 & 27 & $<1.0 \mathrm{E}-12$ & $0.00 \mathrm{E}+00$ \\
\hline 19 & 6 & 0.5 & 0.1 & 0.0 & $25 \mathrm{cc} / \mathrm{kg} \mathrm{H} 2$ & 360 & 25 & $\sim 2.0 \mathrm{E}-11$ & $4.00 \mathrm{E}-06$ \\
\hline 20 & 10 & 0.5 & 0.01 & 0.0 & $25 \mathrm{cc} / \mathrm{kg} \mathrm{H} 2$ & 360 & 25 & $\sim 3.0 \mathrm{E}-12$ & $1.00 \mathrm{E}-06$ \\
\hline 21 & 63 & 0.5 & 0.001 & 0.0 & $25 \mathrm{cc} / \mathrm{kg} \mathrm{H} 2$ & 360 & 24 & $\sim 1.0 \mathrm{E}-12$ & $2.00 \mathrm{E}-06$ \\
\hline 22 & 557 & 0.5 & 0.001 & 2.5 & $25 \mathrm{cc} / \mathrm{kg} \mathrm{H} 2$ & 360 & 24 & $\sim 1.0 \mathrm{E}-12$ & $5.00 \mathrm{E}-06$ \\
\hline 23 & 144 & --- & const $\mathrm{K}$ & --- & $25 \mathrm{cc} / \mathrm{kg} \mathrm{H} 2$ & 360 & 24 & $<1.0 \mathrm{E}-12$ & $1.00 \mathrm{E}-06$ \\
\hline 24 & 48 & 0.5 & 0.01 & 0.0 & $25 \mathrm{cc} / \mathrm{kg} \mathrm{H} 2$ & 360 & 23 & $\sim 3.0 \mathrm{E}-12$ & $3.00 \mathrm{E}-06$ \\
\hline 25 & 61 & 0.5 & 0.001 & 0.0 & $25 \mathrm{cc} / \mathrm{kg} \mathrm{H} 2$ & 360 & 22 & $\sim 3.0 \mathrm{E}-12$ & $2.00 \mathrm{E}-06$ \\
\hline 26 & 61 & 0.5 & 0.001 & 2.5 & $25 \mathrm{cc} / \mathrm{kg} \mathrm{H} 2$ & 360 & 22 & $\sim 1.0 \mathrm{E}-12$ & $1.00 \mathrm{E}-06$ \\
\hline 27 & 265 & --- & const $\mathrm{K}$ & --- & $25 \mathrm{cc} / \mathrm{kg} \mathrm{H} 2$ & 360 & 22 & $<1.0 \mathrm{E}-12$ & $2.00 \mathrm{E}-06$ \\
\hline 28 & 265 & 0.5 & $12 \mathrm{~s} / 12 \mathrm{~s}$ & 2.77 & $25 \mathrm{cc} / \mathrm{kg} \mathrm{H} 2$ & 360 & 22 & $<1.0 \mathrm{E}-12$ & $0.00 \mathrm{E}+00$ \\
\hline 29 & 186 & 0.5 & $12 \mathrm{~s} / 500 \mathrm{~s}$ & 2.64 & $25 \mathrm{cc} / \mathrm{kg} \mathrm{H} 2$ & 360 & 22 & $<1.0 \mathrm{E}-12$ & $1.00 \mathrm{E}-06$ \\
\hline 30 & 291 & 0.5 & $500 \mathrm{~s} / 12 \mathrm{~s}$ & 2.64 & $25 \mathrm{cc} / \mathrm{kg} \mathrm{H} 2$ & 360 & 22 & $<1.0 \mathrm{E}-12$ & $1.00 \mathrm{E}-06$ \\
\hline 31 & 185 & --- & const $\mathrm{K}$ & --- & $25 \mathrm{cc} / \mathrm{kg} \mathrm{H} 2$ & 360 & 21 & $<1.0 \mathrm{E}-12$ & $0.00 \mathrm{E}+00$ \\
\hline
\end{tabular}


Table 5

\begin{tabular}{|c|c|c|c|c|c|c|c|c|c|c|c|c|}
\hline & Element & $\mathrm{Ni}(\mathrm{K})$ & $\mathrm{Cr}(\mathrm{K})$ & $\mathrm{Fe}(\mathrm{K})$ & $\operatorname{Mn}(\mathrm{K})$ & $\mathrm{Al}(\mathrm{K})$ & $\mathrm{Si}(\mathrm{K})$ & $\mathrm{P}(\mathrm{K})$ & $\mathrm{S}(\mathrm{K})$ & $\operatorname{Ti}(\mathrm{K})$ & $\mathrm{Nb}(\mathrm{L})$ & $\mathrm{Ta}(\mathrm{L})$ \\
\hline \multirow{2}{*}{$\begin{array}{l}\text { alloy } 52 \\
\text { IG crack }\end{array}$} & Atomic \% & 56.38 & 32.79 & 9.68 & 0 & 0.57 & 0.18 & 0 & 0 & 0.3 & 0 & 0.06 \\
\hline & Uncert. \% & 0.36 & 0.24 & 0.14 & 100 & 0.02 & 0.01 & 100 & 100 & 0.02 & 100 & 0.11 \\
\hline \multirow[b]{2}{*}{$\begin{array}{c}\text { alloy } 52 \\
\text { TG crack }\end{array}$} & Atomic \% & 57.63 & 31.11 & 8.86 & 0 & 1.4 & 0.44 & 0 & 0 & 0.22 & 0 & 0.3 \\
\hline & Uncert. \% & 0.4 & 0.25 & 0.14 & 100 & 0.04 & 0.02 & 100 & 100 & 0.02 & 100 & 0.14 \\
\hline \multirow[b]{2}{*}{ alloy $52 \mathrm{M}$} & Atomic $\%$ & 57.12 & 34.49 & 7.49 & 0.64 & 0 & 0.1 & 0 & 0 & 0 & 0.13 & 0 \\
\hline & Uncert. \% & 0.41 & 0.29 & 0.14 & 0.1 & 100 & 0.01 & 100 & 100 & 100 & 0.04 & 100 \\
\hline \multirow[b]{2}{*}{ alloy 152} & Atomic \% & 53.66 & 31.77 & 7.84 & 3.79 & 0 & 1.93 & 0 & 0 & 0.05 & 0.68 & 0.24 \\
\hline & Uncert. \% & 0.41 & 0.29 & 0.15 & 0.14 & 100 & 0.03 & 100 & 100 & 0.02 & 0.07 & 0.16 \\
\hline
\end{tabular}

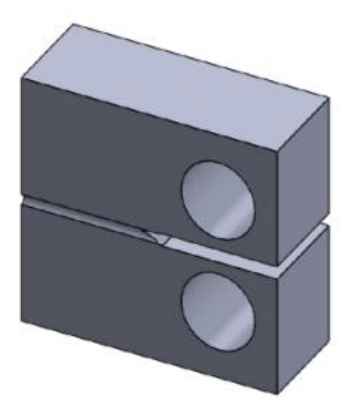

(a) 3-D image

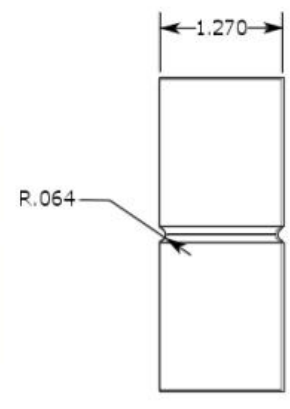

(b) side view

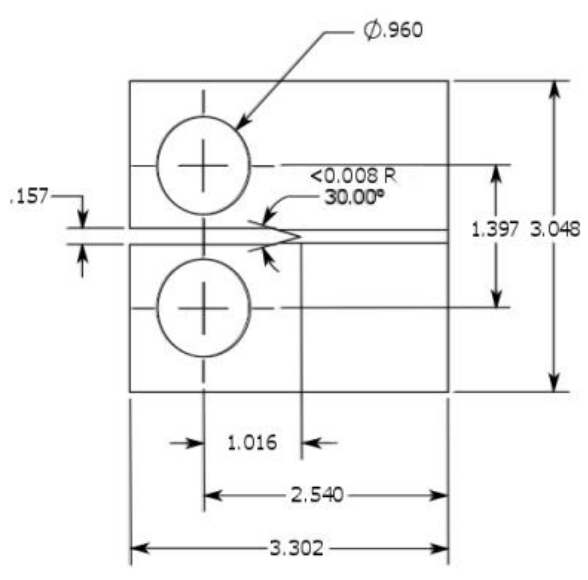

(c) front view

\section{Figure 1}




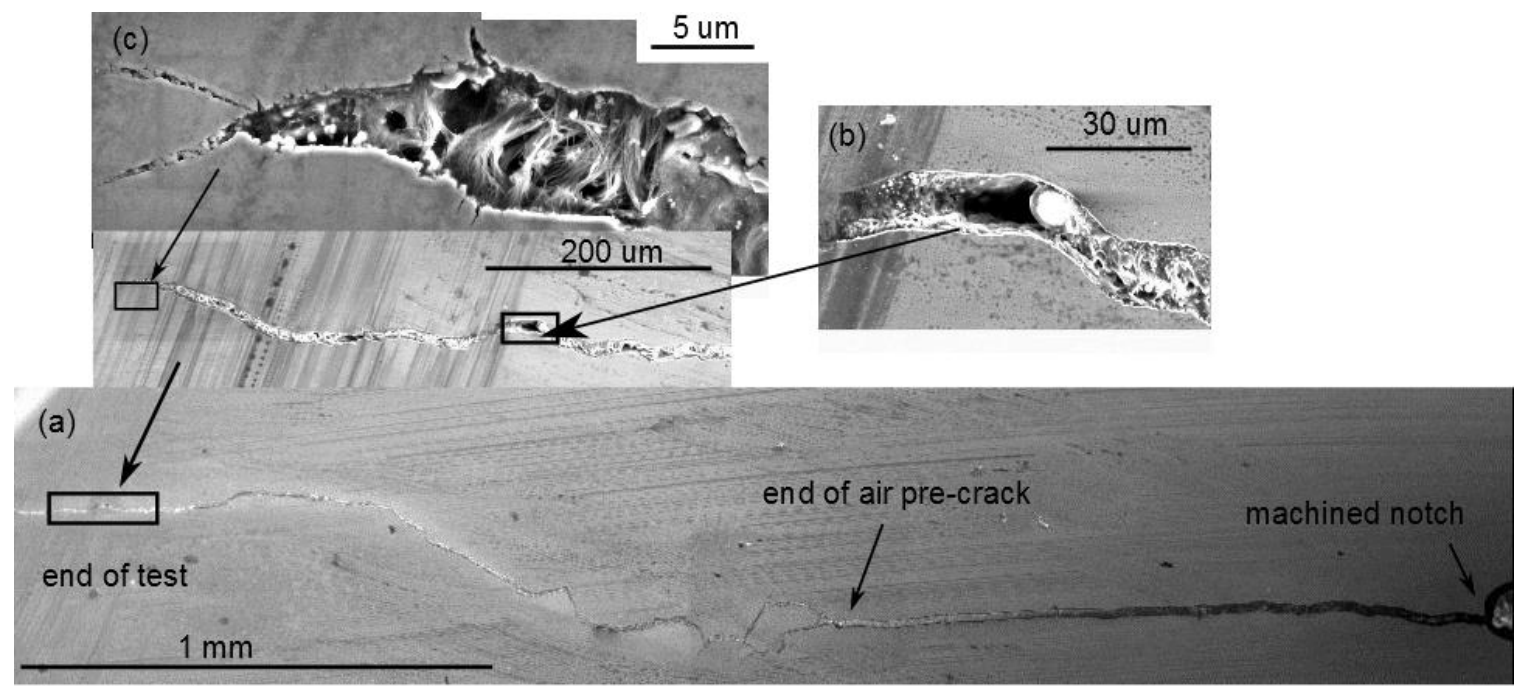

Figure 2

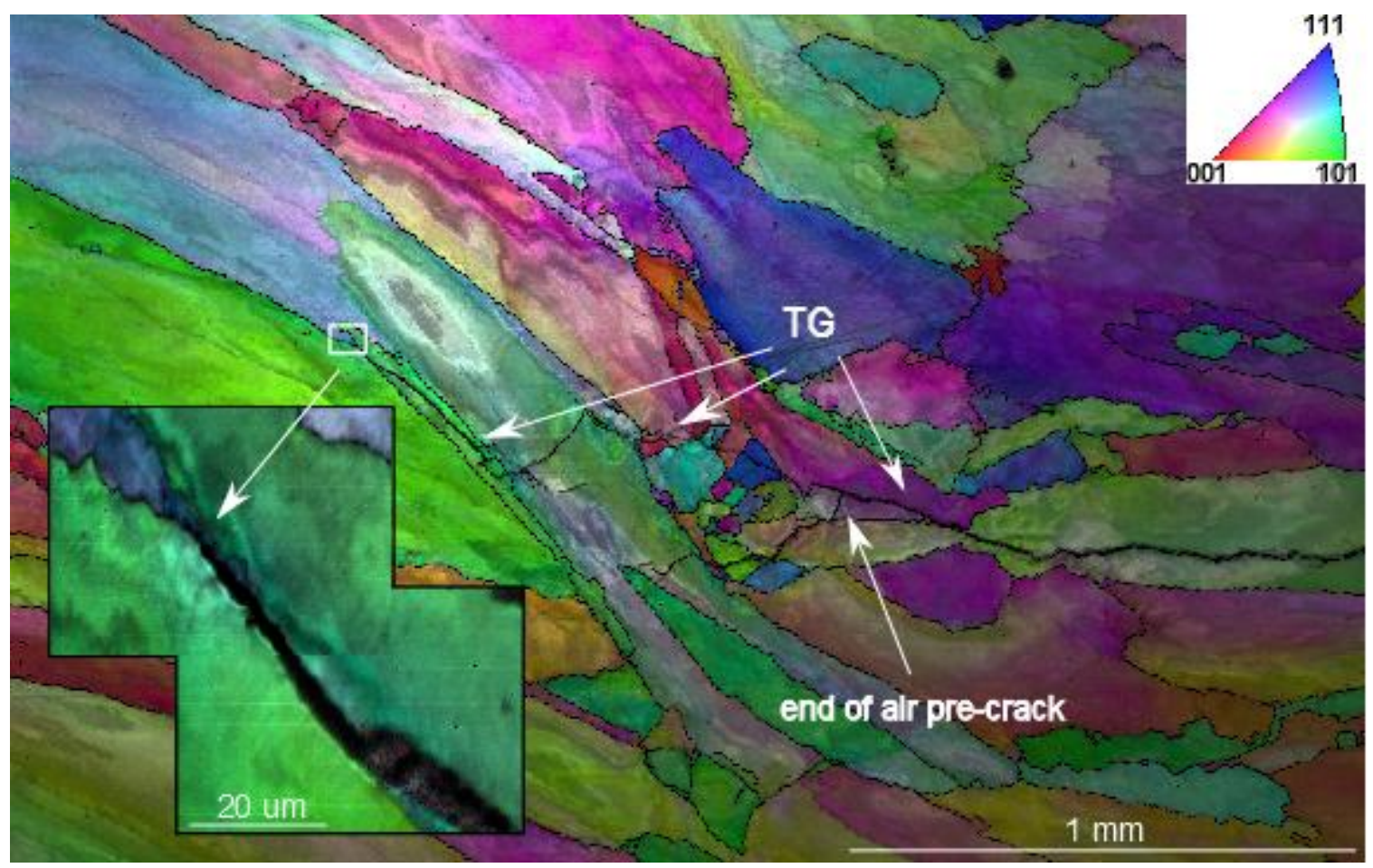

Figure 3 


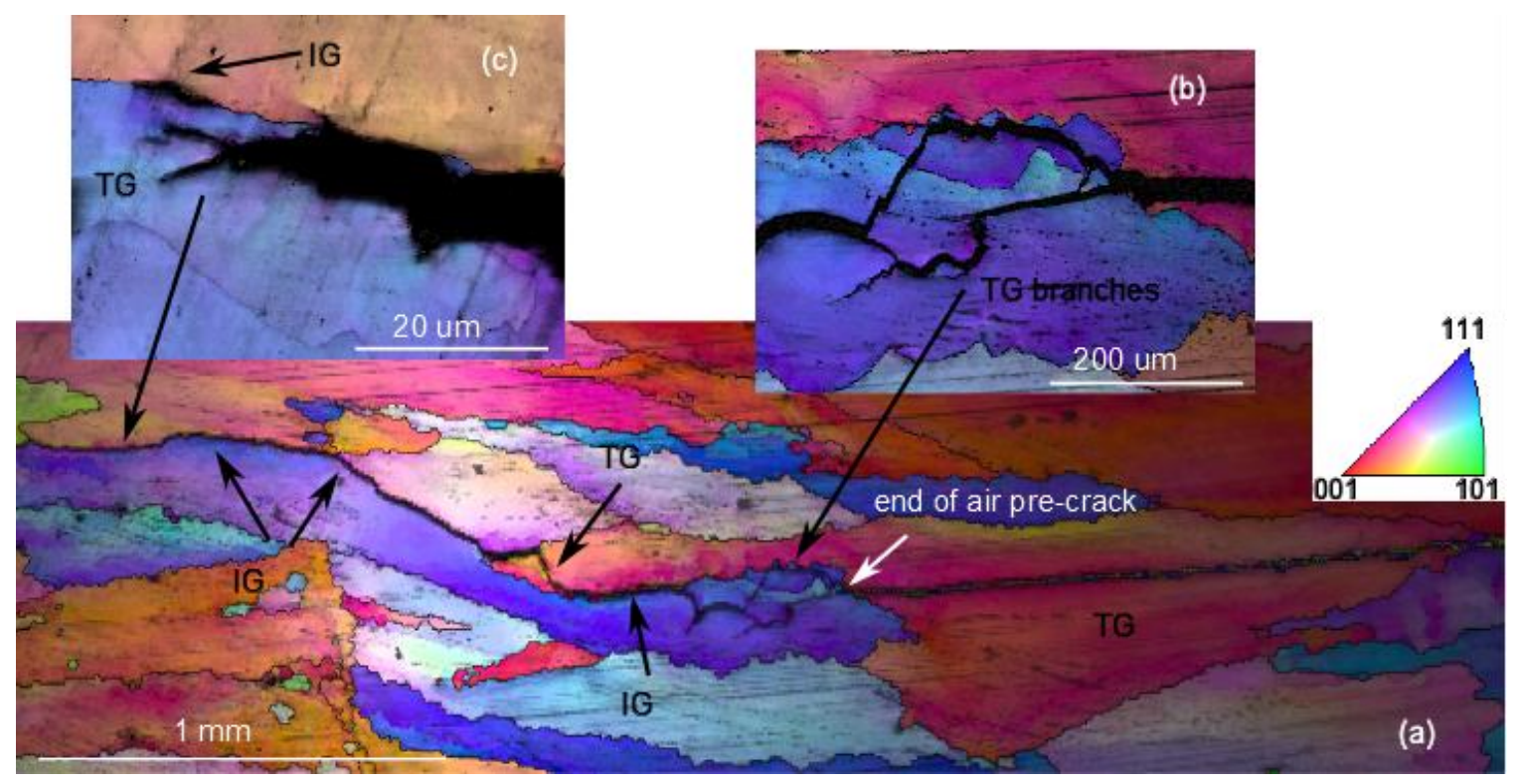

Figure 4

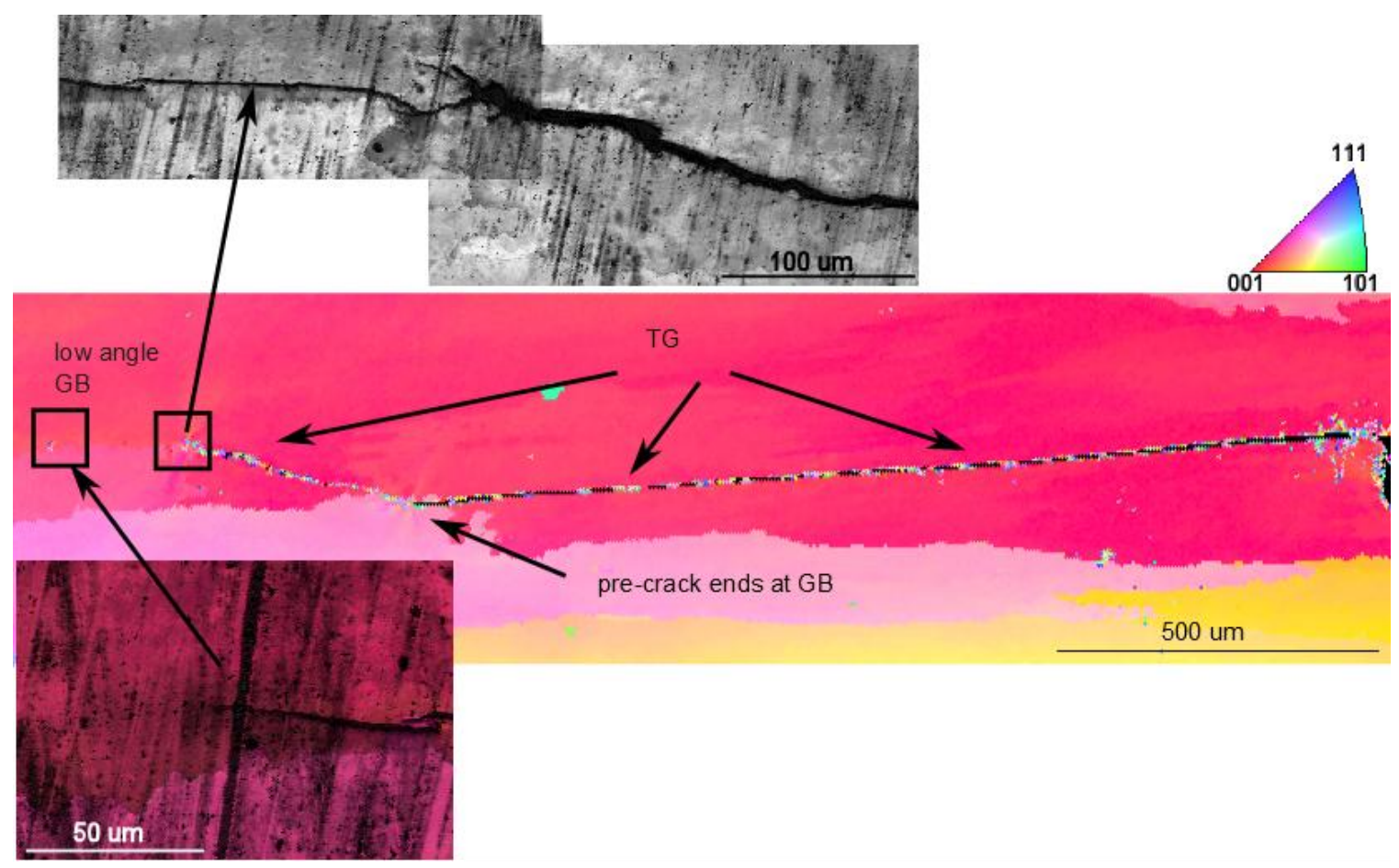

Figure 5 

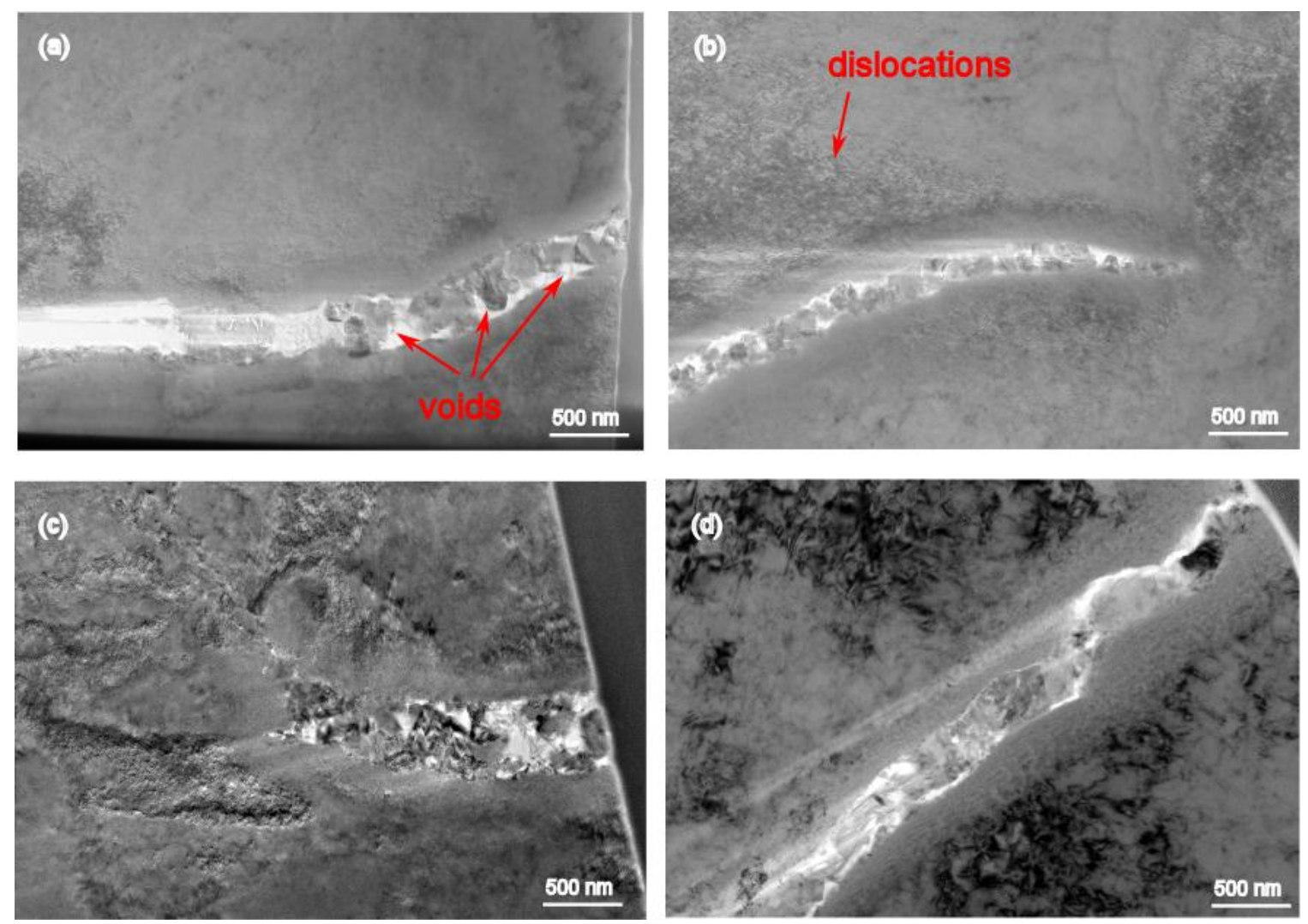

Figure 6 


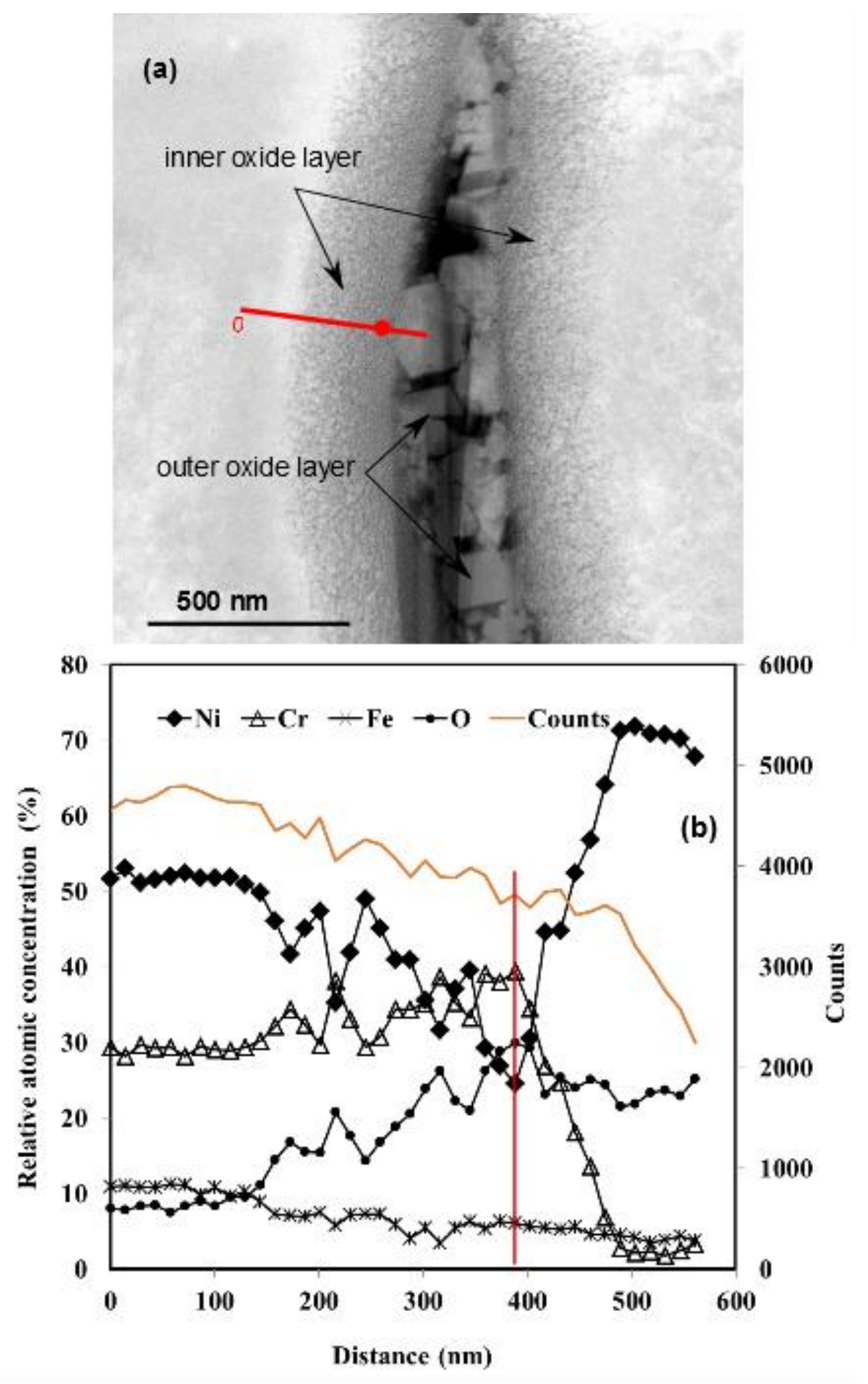

Figure 7 

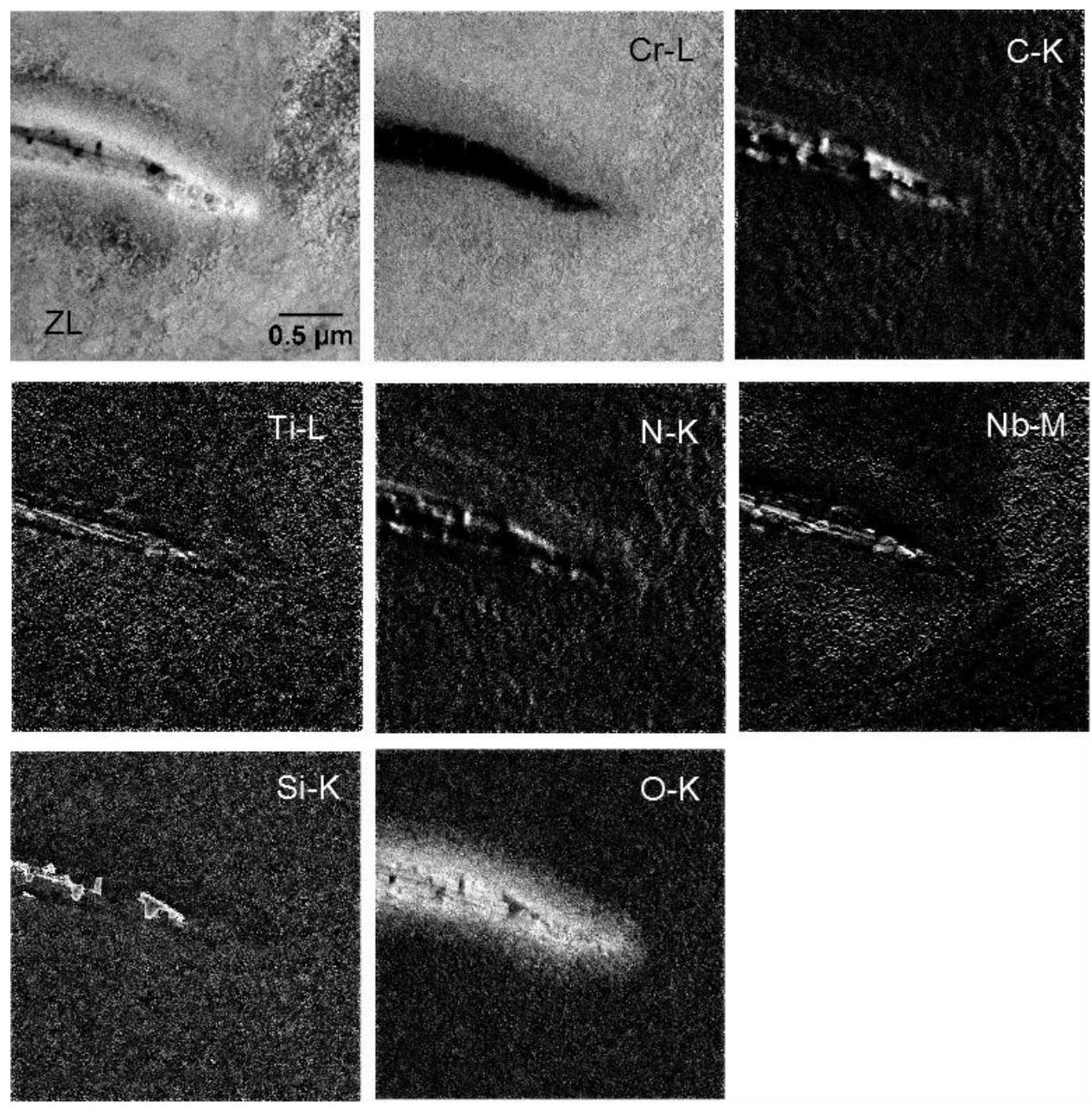

Figure 8 

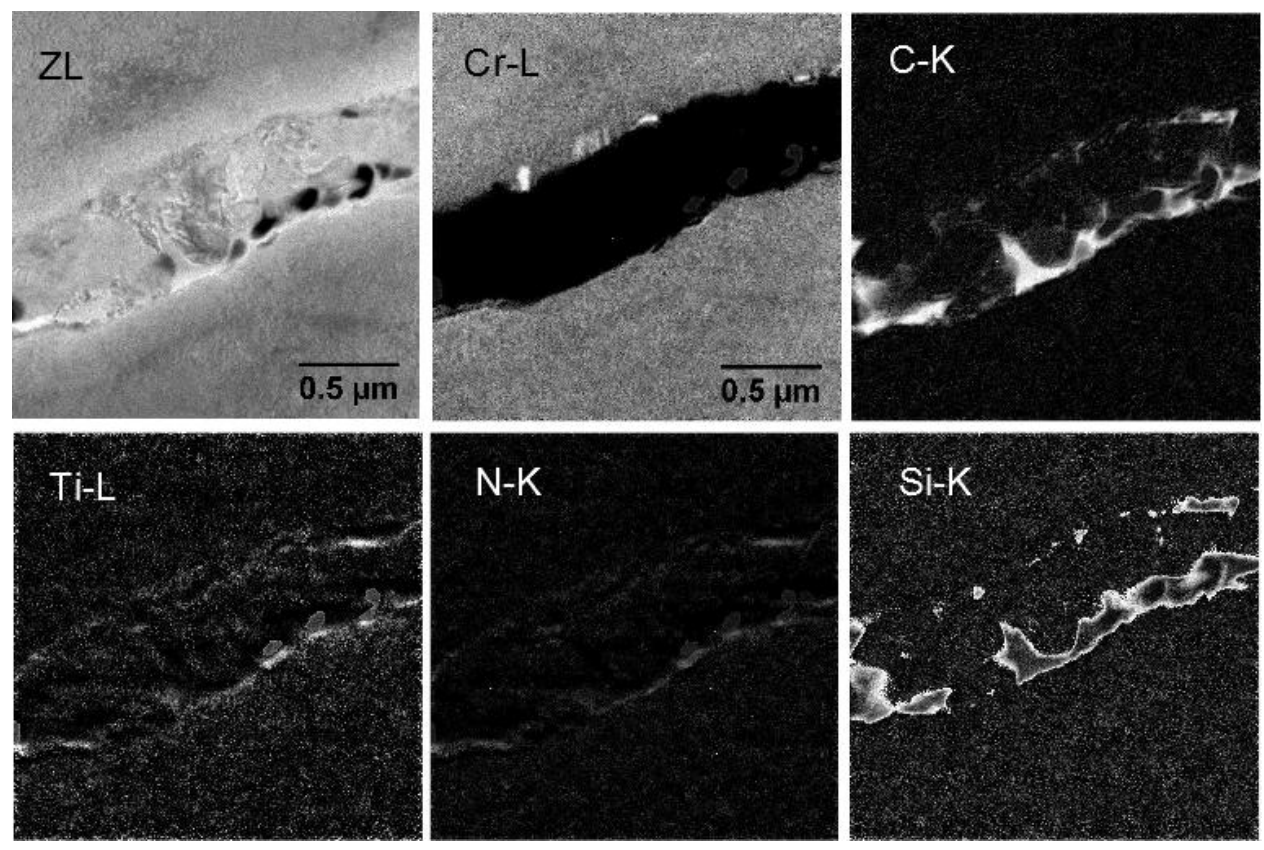

Figure 9 

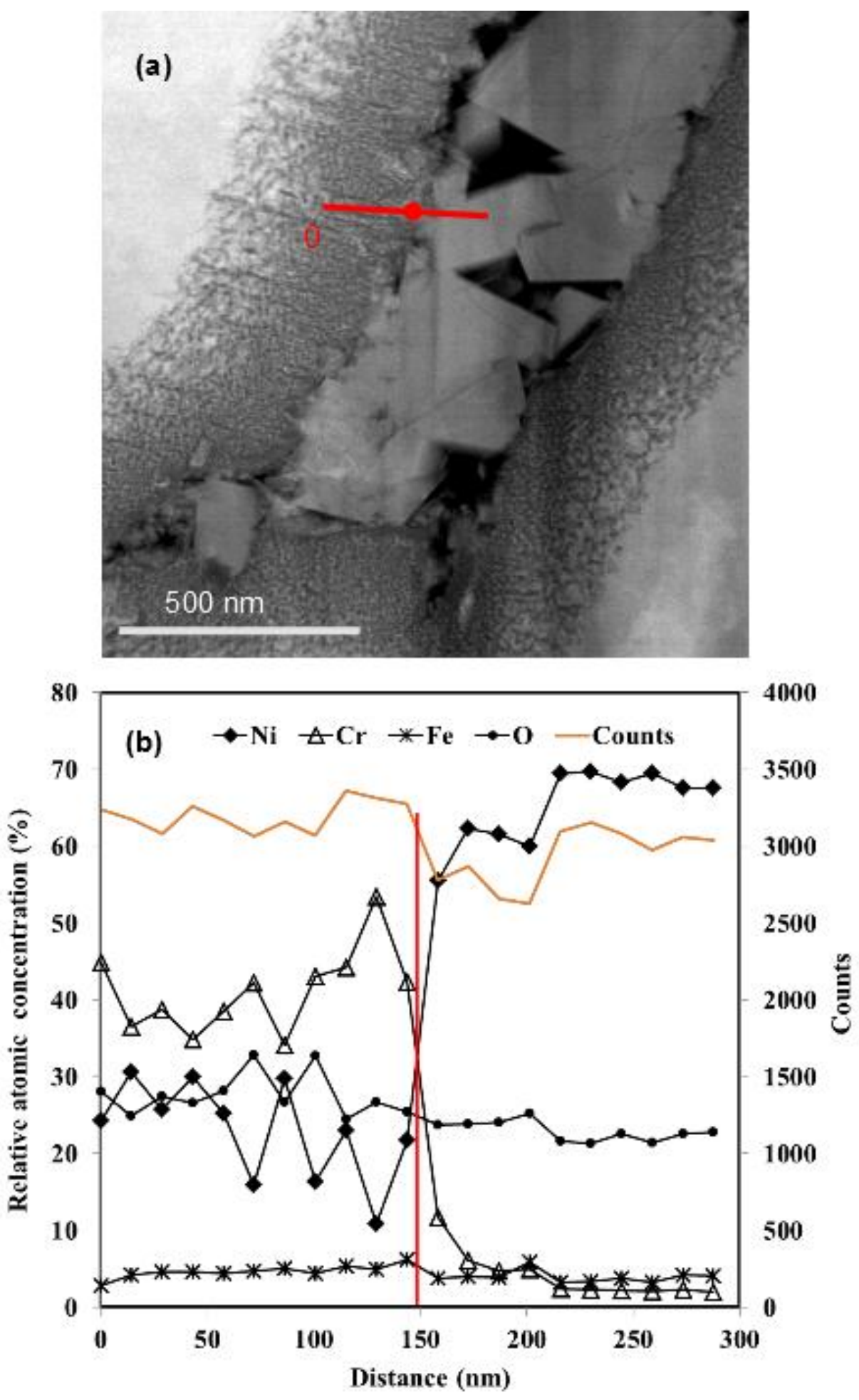

Figure 10 

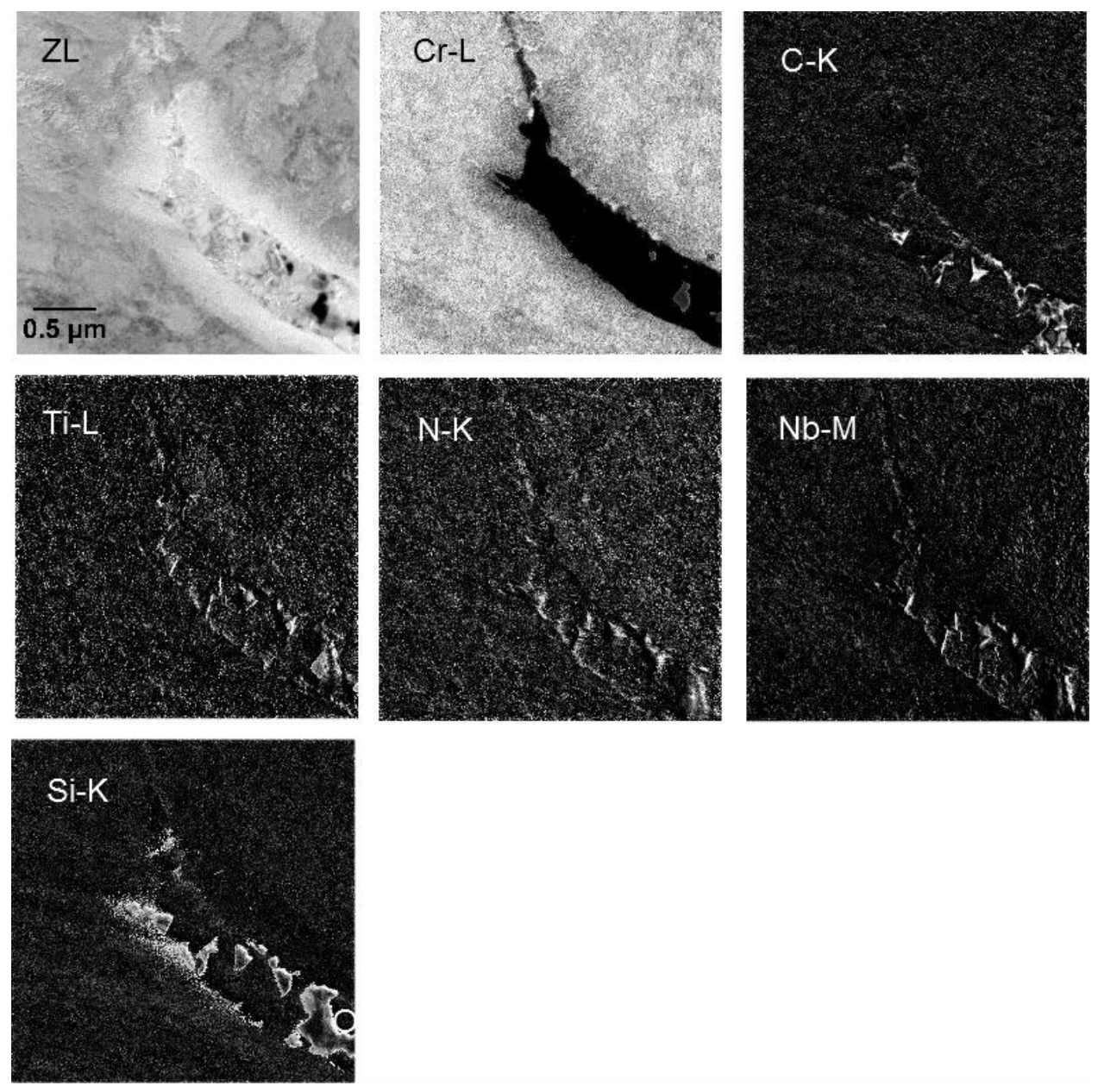

Figure 11 


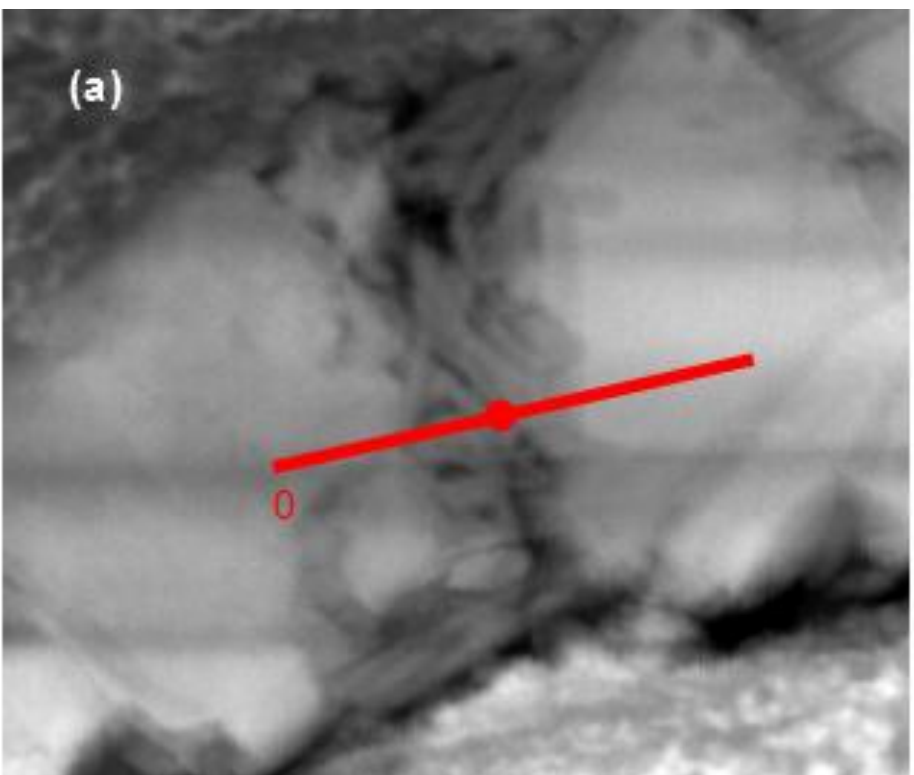

\section{$50 \mathrm{~nm}$}

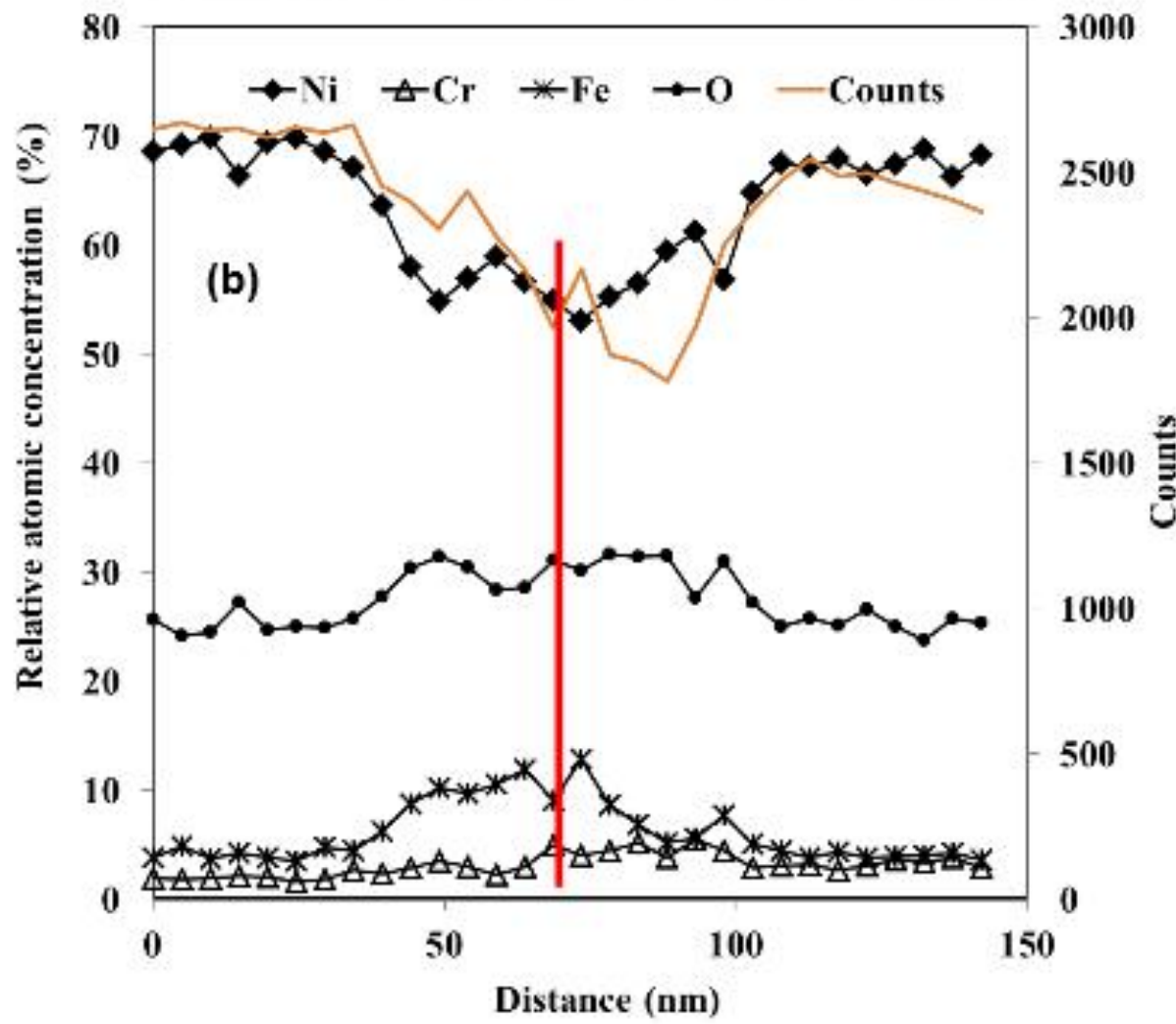

Figure 12 

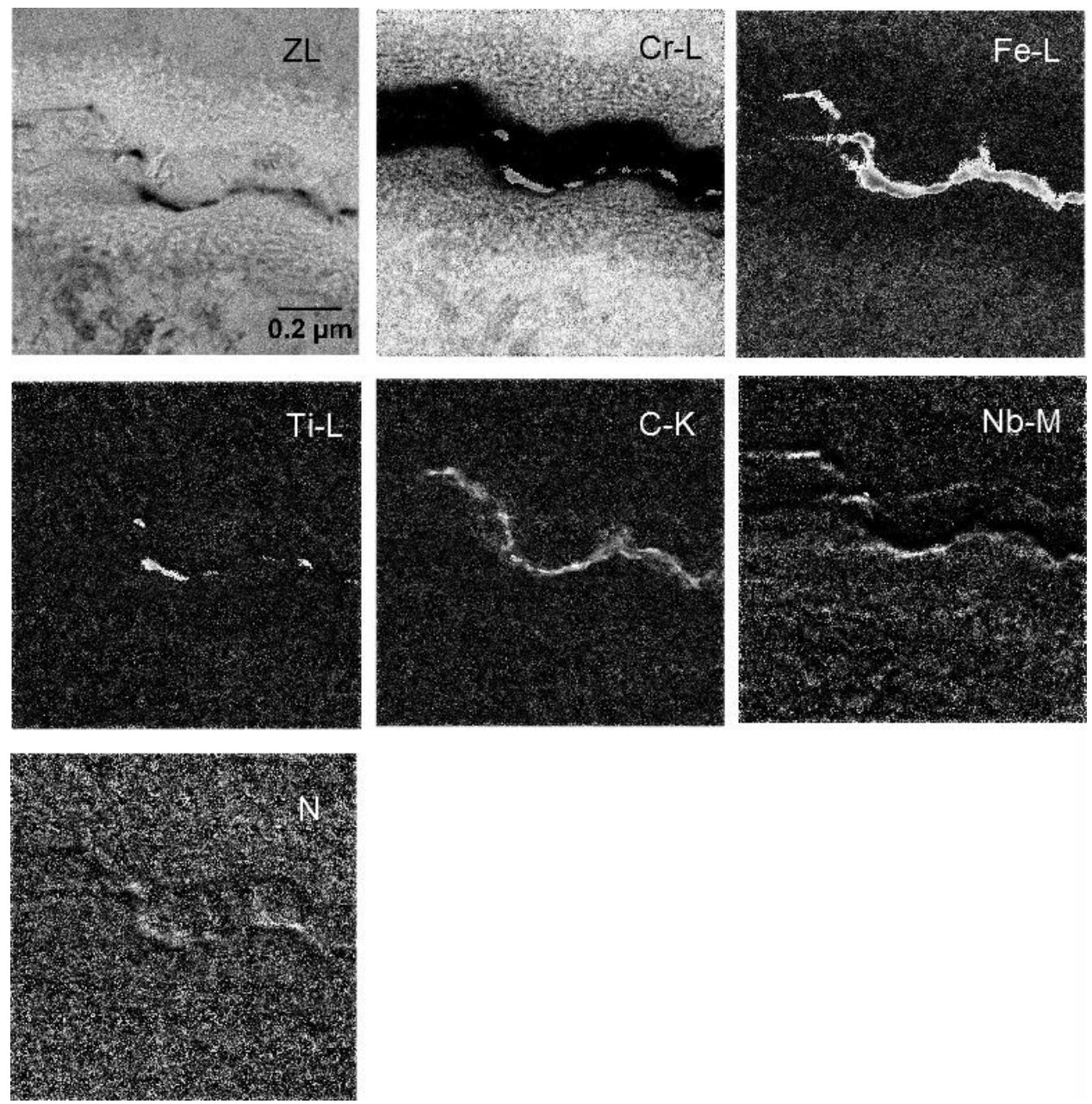

Figure 13 